\title{
Do Incumbents Improve Service Quality in Response to Entry? Evidence from Airlines' On-Time Performance
}

\author{
Jeffrey T. Prince and Daniel H. Simon*
}

September 2010

\begin{abstract}
We examine if and how incumbent firms respond to entry, and entry threats, using non-price modes of competition. Our analysis focuses on service quality within the airline industry. We find that incumbent on-time performance actually worsens in response to entry, and even entry threats, by Southwest Airlines. Given Southwest's general superiority in on-time performance, this result is consistent with equilibria of theoretical models of quality and price competition, which generally predict differentiation along quality. We corroborate this intuition with further analysis, showing there is no notable response by incumbents when an airline with average on-time performance (Continental) threatens to enter or enters a route.
\end{abstract}

\footnotetext{
* Jeffrey Prince is at the Kelley School of Business at Indiana University, and Daniel Simon is at the School of Public and Environmental Affairs at Indiana University. They can be reached at jeffprin@indiana.edu and simond@indiana.edu. The authors thank Chad Syverson, Mike Mazzeo, Nick Rupp, Itai Ater, Roger Betancourt, and several participants at the International Industrial Organization Conference for helpful suggestions. All errors are ours.
} 


\section{Introduction}

As evidenced by the recent explosion of research on differentiated products competition, understanding how firms and products compete along dimensions other than price (e.g., quality) is both very important from a management and policy viewpoint, and highly relevant to many industries. One question of particular interest to academics and practitioners is how firm entry into a market impacts quality provision. From theoretical and empirical analyses, much is known about the relationship between entry and price, and even the threat of entry and price. However, very little is known about the effect of entry (or the threat of entry) on firms' provision of quality.

In this paper, we examine if and how incumbents adjust their quality provision in response to entry and entry threats. Specifically, we assess how incumbent airlines adjust their on-time performance in response to entry and entry threats by Southwest Airlines. The airline industry provides an ideal setting to conduct this analysis since data on airline on-time performance provide a good measure of product quality and are readily available, and entry and entry threats by Southwest are easily observable (Goolsbee \& Syverson 2008).

This paper builds on and contributes to three streams of literature. The first focuses on non-price responses to entry. While it has been widely established, both theoretically and empirically, that prices tend to fall in response to increased competition (see, e.g., Tirole 2000, Bain 1951), the relationship between quality and competition is far more ambiguous. Theory papers have found the relationship to be positive (Schmalensee 1974), negative (Gal-Or 1983), and insignificant (Swan 1970). Others suggest that it depends on modeling assumptions (Schmalensee 1979, Banker et al. 1998). While theoretical work is inconclusive, empirical studies have generally found a positive relationship between market competition and quality (e.g., Domberger \& Scherr 1989; Mazzeo 2003). However, nearly all of these studies use crosssectional data, making causal inference difficult. Moreover, most of this research analyzes the relationship between market structure and average quality provision, including any entrants. Very little of this work focuses directly on the incumbents' responses to entry. By using panel data, and excluding the entrants from our data, we are able to isolate the incumbents' quality response to entry and entry threats.

The second stream of related research focuses on strategic entry deterrence. Several seminal theoretical papers (e.g., Dixit 1979, Spence 1981, Klemperer 1987) provide rationales 
for firms engaging in competitive actions before new competitors enter. However, very few empirical papers have tested for such behavior. Two recent examples are Dafny (2005), which tests for strategic investment, and Goolsbee and Syverson (2008), which tests for strategic price cutting. This paper adds to this literature by being the first to test for strategic quality provision in response to an entry threat.

The third stream of related research looks at on-time performance in the airline industry. One of the difficulties in assessing non-price responses to entry is measuring non-price forms of competition. Recently, several papers have made use of an easily observable measure of service quality in the airline industry: on-time performance. For example, Mazzeo (2003) and Rupp, Owens, and Plumly (2003) examine the impact of market structure on on-time performance. Prince and Simon (2009) assess the influence of multimarket contact on on-time performance. In addition, Rupp (2005) examines the causes of flight delays and cancellations, Januszewski (2004) studies the impact of on-time performance on demand for air travel, and Mayer \& Sinai (2003) assess the impact of hubbing effects and congestion externalities on on-time performance. Collectively, this research indicates that on-time performance improves as markets become more competitive. However, none of these papers directly analyzes the effects of entry (or threat of entry). The relationship they find between quality provision and market structure is an average effect, including entrants' quality levels; they do not isolate incumbents' responses to entry, nor do they allow them to depend on the characteristics of the entrant.

We similarly exploit airline on-time performance in order to assess whether incumbent airlines adjust their service quality in response to entry and entry threats by Southwest. Perhaps surprisingly, our results indicate that airlines’ on-time performance actually worsens in both cases. Regarding actual entry, we argue that this result is consistent with predictions from theoretical models of price and quality competition, which predict that firms will differentiate along the quality dimension in equilibrium. Given Southwest's well-known superiority in ontime performance, its entry into a market will tend to push incumbents "down" this dimension of quality as they differentiate away from Southwest.

Furthermore, when Southwest threatens to enter a market, incumbents may have an incentive to move to the long-run (post entry) equilibrium of providing lower quality even before entry occurs. We posit two reasons for this. First, customer demand is unlikely to immediately respond to changes in on-time performance; a late arrival on a current flight may affect 
passengers’ future flight purchases, which may not occur for many weeks or months. Second, factors that influence on-time performance may be costly to adjust (e.g., laying off employees). Therefore, when Southwest's entry is imminent, incumbents may find reducing on-time performance below current equilibrium levels to be profit enhancing, since the consequences for demand likely won't occur until after Southwest has entered, and because their new equilibrium level of on-time performance is lower anyway. Neither of these explanations is suggestive of entry deterrence, but rather profit-maximizing behavior in the face of an impending new equilibrium ${ }^{1}$.

It is clear that our proposed explanation for why on-time performance worsens in response to entry by Southwest hinges on Southwest possessing a competitive advantage along this quality dimension. In contrast, if the entrant had a similar cost structure, we would not expect to find such a response, since any differentiating movements by incumbents could be up or down the quality spectrum (in section 3.3, we provide evidence of Southwest's superiority in on-time performance). We test this idea by comparing the responses of incumbents threatened by entry from Southwest with those of incumbents threatened by an entrant that offers more average quality, Continental. Our results are consistent with this hypothesis, as we find virtually no change in on-time performance by incumbents in response to entry or entry threats by Continental.

The implications of these findings are several. To begin, they improve our understanding of how airlines compete. We demonstrate that entry and entry threats by at least some airlines can cause incumbents to reduce their on-time performance as the firms move to a new equilibrium. In addition, our analysis provides new insights into the ways firms respond to entry along non-price dimensions. Prior theoretical and empirical work relating market structure to average quality provision often suggests that average quality and competition are positively correlated. Our results show that, even in an industry where this relationship appears to hold (e.g., Mazzeo 2003), it does not imply that each firm will improve its quality in response to new competition, or to the threat of it. Consequently, customers should not necessarily expect improved quality from incumbents when a new rival enters or threatens to enter a market. Taking a broader view, our results show that the welfare implications of entry, at least with

\footnotetext{
${ }^{1}$ At the end of Section 2, we briefly discuss how this action could be part of a broader entry deterrence strategy, consistent with the one highlighted in Goolsbee and Syverson (2008).
} 
regard to quality, can depend on the entrant, and may involve the average consumer actually experiencing lower quality.

\section{Theoretical Overview}

In addition to price, airlines compete along many dimensions. Differentiating factors include: on-time performance, destinations served, flight times and frequencies, aircraft size, and customer service. Airlines compete along these dimensions in many different markets, and against many different combinations of competitors with differing characteristics. In contrast, theoretical models of non-price competition are relatively simple, in order to be tractable. Consequently, it is beyond the scope of this paper to develop a theoretical model explaining nonprice competition among airlines. However, to build intuition for our empirical results, we review and draw upon related theoretical work (and relevant empirical findings) on non-price competition.

\subsection{Models of Quality Competition}

We begin by discussing models of quality (and price) competition in duopoly, where firms can differentiate only along a single dimension. These are the models most heavily analyzed by the theoretical literature, apparently for tractability reasons. We discuss competition along multiple dimensions and across more than two firms later in this subsection.

For duopoly models with a single quality dimension, the general conclusion that emerges from equilibrium analysis is that firms will differentiate (often maximally) along the quality dimension (see Tirole 2000). Following Tirole (2000) and Shaked and Sutton (1982), we lay out a simple two-stage model of two identical firms competing, first in quality and then in price. We then solve for equilibrium. Subsequently, we compare the equilibrium outcomes from this scenario to those under monopoly, and to those for a duopoly in which the firms have differing cost structures.

In the model, consumers' preferences are represented by $U=\theta s-p$ if they consume one unit of a good with quality $s$ and price $p$. They can consume at most one unit, and have $U=0$ if they consume no units. The parameter $\theta$ represents taste for quality and is assumed to be distributed uniformly across the population of consumers between $\underline{\theta}$ and $\bar{\theta}=\underline{\theta}+1$. Firms play a two-stage game. In the first stage, they choose qualities (s), and in the second stage they 
choose prices (p). After firms choose prices, consumers observe prices and quality and then choose which product to buy.

To begin, we consider the case where there are two firms, Firm 1 and Firm 2. We assume each firm has a unit cost of production equal to $c * s_{i}^{2}, i \in\{1,2\}$. In solving for equilibrium locations, we solve for $s_{H}$ and $s_{L}$, where, without loss of generality, we assume $s_{H} \geq$ $s_{L}$. Following Tirole (2000), we simplify the analysis by assuming a minimal level of consumer heterogeneity and that the market is “covered," i.e., each consumer buys one of the two brands 2 . It is easy to show that equilibrium quality choices in the first stage will be:

$$
\begin{aligned}
& s_{L}^{*}=\frac{\bar{\theta}+\underline{\theta}}{4 c}-\frac{3}{8} \\
& s_{H}^{*}=\frac{\bar{\theta}+\underline{\theta}}{4 c}+\frac{3}{8}
\end{aligned}
$$

Thus, we have two equilibrium sets of quality choices for Firms 1 and $2:\left(\frac{\bar{\theta}+\theta}{4 c}-\frac{3}{8}, \frac{\bar{\theta}+\theta}{4 c}+\frac{3}{8}\right)$ and $\left(\frac{\bar{\theta}+\underline{\theta}}{4 c}+\frac{3}{8}, \frac{\bar{\theta}+\underline{\theta}}{4 c}-\frac{3}{8}\right)$. We note that the solution clearly demonstrates that firms will differentiate in equilibrium. For the cases of linear marginal costs or $\mathrm{c}=0$, we would have found the familiar result of maximal differentiation. As we see from our example, maximal differentiation is not a robust finding. However, as Tirole (2000) notes, "the principle of differentiation is more robust."

Using the above example, we can assess how equilibrium qualities change when the market moves from one to two firms. Here, we assume that there are no fixed costs of changing quality (e.g., there is no fixed cost of switching from $s=.2$ to $s=.4$ ). To make the comparison, we first solve for a monopolist's optimal quality in the same demand setting. It is again easy to show that, in the first stage, the monopolist will choose ${ }^{3}$ :

$$
s^{*}=\frac{\bar{\theta}}{5 c}
$$

Now, if we make the benign assumption that $\underline{\theta}<\frac{5 c}{4}-1$, this implies that the monopoly quality level is between the two duopoly quality levels. Consequently, when a second firm enters and

\footnotetext{
${ }^{2}$ These assumptions, and full details of the solution, are made explicit in the Appendix.
}

${ }^{3}$ Details of the solution are in the Appendix. 
the two firms move to the duopoly equilibrium quality levels, the incumbent may move to a higher or lower quality level, depending on which of the two possible equilibria ensues.

To help provide intuition as to how an incumbent monopolist would change its quality offering in response to entry, we consider the case where the entrant has a different cost structure from the incumbent. This case is especially pertinent to our empirical setting, because it is likely that Southwest has a different (lower) cost structure than most other airlines. Let the incumbent have unit cost of production equal to $c_{1} * s_{1}^{2}$ and the entrant have unit cost of production equal to $c_{2} * s_{2}^{2}$, where $c_{2}<c_{1}$. Given this cost structure, we again solve for the duopoly equilibrium.

The details of the solution are in the Appendix, but a couple of key points emerge. First, we again find that firms will differentiate in equilibrium. Second, while it is possible that the high-cost firm (the incumbent) would provide high quality and the low-cost firm (the entrant) would provide low quality in equilibrium, intuitively, such an outcome seems unlikely. In particular, we show that if costs of production are "reasonably" low (specifically, $c_{1}+c_{2}<\frac{1}{2}+$ $\left.\frac{\theta}{2 \bar{\theta}}\right)^{4}$, then for any given pair of quality choices, overall profits are unambiguously higher when the high-cost firm provides low quality and the low-cost firm provides high quality. Hence, when this condition holds, then for any equilibrium where the high-cost firm provides higher quality, overall profits would be higher if the firms simply switched places. Of course, this doesn't necessarily imply which equilibrium would ensue, but it does suggest a certain inferiority for any equilibrium with the high-cost firm providing high quality.

We also note that the above analysis assumes that there are no adjustment costs when changing quality provision. In reality, this almost certainly isn't the case. In particular, we might expect it to be especially costly for high-quality firms to adjust quality downward (due to reputational costs). As we note in our data section, Southwest has a very strong reputation for on-time performance, suggesting that downward adjustments in quality would be particularly costly. Although Southwest is an entrant, and therefore has no adjustments to make on the route in question, it may face adjustment costs from its existing “status quo” (e.g., their average

\footnotetext{
${ }^{4}$ Intuitively, the condition, $c_{1}+c_{2}<\frac{1}{2}+\frac{\theta}{2 \bar{\theta}}$, can break down in two ways. First, we could have high $\mathrm{c}_{1}$ and low $\mathrm{c}_{2}$. In this case, the high-cost firm is likely unprofitable whether producing high or low quality; however, the low-cost firm makes more profits producing lower quality (with virtually no threat from the high-quality-producing, high-cost firm) compared to when it produces higher quality (and faces a greater possibility of price competition from its competitor at the low end). Second, it could be that both firms have high costs. In this case, the best hope for either firm to make profits is for the lower-cost firm to provide lower quality, and hence be able to price low enough to generate sales.
} 
performance on other routes they already serve). Hence, if the low-cost (entrant) firm already has built a reputation for high quality in other markets, this would point even more strongly toward an equilibrium where the low-cost firm provides high quality and the high-cost firm provides low quality.

For the above analysis, we restricted our attention to the case where firms differentiate along just one dimension. Of course, in most markets (airlines included), firms compete along many dimensions. The literature in this area generally shows that firms will differentiate along some dimensions and imitate along others (e.g., Ben-Akiva et al. 1989, Neven \& Thisse 1990). Further, if one dimension is sufficiently dominant, firms will maximally differentiate along that dimension and minimally differentiate along all others (Irman \& Thisse 1998) ${ }^{5}$. Although the extant theoretical work on multidimensional differentiation suggests that differentiation should occur on some dimensions, it is not obvious ex ante which dimensions these will be. The small amount of empirical work looking at incumbent non-price response to entry emphasizes this ambiguity. For example, Goolsbee and Petrin (2004) find that cable television quality (in the form of, e.g., number of pay-per-view channels and channel capacity) increases with the entry of direct broadcast satellite. This result suggests minimal differentiation, as cable tries to "keep pace” with satellite. In contrast, Netz and Taylor (2002) find that spatial differentiation of retail gas stations is greater when the number of competitors increases.

Another restriction of note in the above analysis is that we limited our attention to shifts from monopoly to duopoly. While the results for this case are rather clear-cut, they become less so when looking at the relationship between equilibrium quality provision and a general increase in competition. A large amount of theoretical literature in this area assesses how firms' quality provision responds to an increase in the number of competitors. Focusing primarily on durability, Swan (1970) suggested that quality provision was independent of market structure. As summarized in Schmalensee (1979), a series of subsequent papers showed that this independence breaks down when some of Swan’s modeling assumptions are relaxed. Hence, quality can depend on market structure, and model assumptions dictate whether or not this is the case. More recent work has reiterated this conclusion. For example, Banker et al. (1998) show

\footnotetext{
${ }^{5}$ This more extreme finding has been challenged in the empirical literature. Specifically, Netz and Taylor (2002) state that: "Contrary to the predictions of the theoretical literature, we find that firms increase spatial differentiation as differentiation in other attributes increases."
} 
that equilibrium quality in a market with $\mathrm{N}$ symmetric firms may be increasing or decreasing in $\mathrm{N}$, depending on parameters underlying costs and demand.

Empirical research has often found a positive relationship between quality and competition. For example, Domberger \& Scherr (1989) find that customer satisfaction in legal services increases with competition. Similarly, Rupp et al. (2003) and Mazzeo (2003) find that on-time performance improves with competition, and Economides et al. (2008) show that new entry increases the number of types of local phone plans offered. Domberger et al. (1995) find a weak, but positive, relationship between competition and cleaning service quality. In sum, while the theoretical literature indicates that the relationship between quality and market structure can be of any sign, the empirical literature suggests that this relationship is often positive in practice.

However, in many studies looking at quality's relationship with competition, it is either implicitly assumed that firms will not want to differentiate along the quality dimension ${ }^{6}$ of interest, or any differentiation is hidden within average measures. For example, if a market is a monopoly and a new firm enters (creating a duopoly), the average quality provided by the firms may rise. However, this could be the result of the two firms providing equal quality that is higher than the monopoly level, or it could be the new entrant providing high (low) quality while the incumbent chooses to offer low (high) quality. Consequently, the empirical measures of average market quality are not especially informative when attempting to assess how incumbents react to entry. One must directly measure incumbent quality, excluding new entrants.

In our setting, the following key points emerge. If on-time performance is a dimension along which airlines choose to differentiate in equilibrium, incumbent airlines will likely adjust their on-time performance away from Southwest's when they enter. Further, Southwest's demonstrated superiority in on-time performance is suggestive of lower marginal costs for quality provision and high (downward) adjustment costs if they choose to provide low quality. Consequently, it is likely that Southwest will choose to provide high quality, and the incumbents will differentiate themselves from Southwest by providing worse on-time performance. It is useful to note here that this prediction only applies to the case where the entrant is superior in ontime performance; if instead the entrant has a similar cost structure to the incumbents and similar adjustment costs, differentiation could imply movement in either direction, resulting in an

\footnotetext{
${ }^{6}$ This assumption is actually explicit in papers like Banker et al. (1998), which assumes a symmetric equilibrium.
} 
ambiguous overall effect. These insights provide the basis for our primary empirical analysis below.

\subsection{Quality Provision and Entry Threats}

The above discussion explains how incumbent quality may decrease in response to entry by firms with higher quality levels. In this subsection, we discuss reasons why incumbents may have an incentive to move to the long-run (post entry) equilibrium, providing lower quality when there is only a threat, and entry has not yet occurred.

There are several reasons why incumbents may initiate a quality response to an entry threat (before entry actually occurs) to deter entry. Examples include capacity commitment (Dixit 1979), long-term contracting (Aghion \& Bolton 1987), and switching costs (Klemperer 1987). However, incumbents performing worse in response to entry threats is inconsistent, both intuitively and analytically, with most entry deterrence strategies ${ }^{7}$.

Why then would firms initiate reductions in quality provision before entry actually occurs? We posit two reasons for this, focusing on the case of airlines competing on on-time performance. First, any changes in on-time performance are likely to have a lagged effect on demand, both because arriving late on a current flight affects passengers' future flight purchases, (which may not occur for many weeks or months), and because reporting of on-time performance data occurs with a lag. When Southwest's entry is imminent, incumbents may find reducing on-time performance below current equilibrium levels to be profit enhancing since the impact on demand likely won't be felt until after Southwest has entered and their new equilibrium level of on-time performance is lower anyway.

Second, if factors that influence on-time performance are costly to adjust (e.g., laying off employees), airlines may have an incentive to gravitate toward post-entry equilibrium quality provision before entry occurs. Specifically, whenever achieving the pre-entry equilibrium quality level requires increases in inputs, airlines may choose to forgo these increases and save adjustment costs, anticipating these inputs will soon be adjusted downward again after Southwest's entry occurs. This behavior would also tend to reduce incumbents' on-time

\footnotetext{
${ }^{7}$ We consider one possible exception at the end of this subsection where firms jointly lower on-time performance and price in order to boost current demand and increase switching costs.
} 
performance before Southwest enters. Neither of these behaviors is suggestive of entry deterrence, but rather profit-maximizing behavior in the face of an impending new equilibrium.

While worsening on-time performance is unlikely to serve as an entry deterrent, we conclude by noting how this action could be part of a broader entry deterrence strategy. Goolsbee \& Syverson (2008) provide evidence that airlines cut prices in response to an entry threat in order to increase current demand and establish long-term loyalty from their customers (e.g., through frequent flyer programs). This price cutting increases switching costs when entry does occur. In the Appendix we show that, under some plausible circumstances, airlines can generate even more current-period demand, while holding profits constant, by reducing quality (and costs), and cutting prices further.

\section{Data}

\subsection{Measurement of Entry and the Threat of Entry}

We examine incumbent quality responses to entry and entry threats using Bureau of Transportation Statistics data on on-time performance by the ten major carriers providing domestic service in the US from 1993-2004. We define a route as a directional origin-destination pair for which at least one carrier provides non-stop service. Moreover, because on-time performance is measured only for individual flights, we restrict our analysis to non-stop service. Our sample comprises the routes that Southwest threatened to enter during our sample time period. Like Goolsbee and Syverson (2008), we exclude routes from our sample where Southwest entered a second endpoint airport simultaneously with actually offering service on the route. In such cases we cannot cleanly identify the threat of entry separately from the actual entry. In total, we observe 277 routes that Southwest threatened to enter, of which Southwest actually entered 225 with nonstop service prior to the end of 2004.

Our general approach to measuring entry and entry threats follows that of Goolsbee and Syverson (2008). They note that when Southwest begins operating in airports on both sides of a route but not the route itself, the likelihood that Southwest will start offering service on that route in the near future rises dramatically. Exploiting this fact, we define a route to be threatened by entry from Southwest when Southwest serves both endpoint airports on a route, but does not offer nonstop service on the route itself. For example, Southwest began flying out of 
Jacksonsville in 1997. Then, in the second quarter of 2004, it entered Philadelphia and began offering service from Philadelphia to Tampa. Although it had not entered the Philadelphia to Jacksonville (or Jacksonville to Philadelphia) route, it now threatened that route because it offered service from both endpoint airports. We define the entry to occur during the quarter in which Southwest begins offering nonstop service on the threatened route. In the above example, entry occurred during the fourth quarter of 2004, when Southwest began offering nonstop service from Jacksonville to Philadelphia and vice versa.

As the above example illustrates, entry and entry threats occur simultaneously for routepairs like Jacksonville to Philadelphia and Philadelphia to Jacksonville; when Southwest threatens or enters the route-pair in one direction, it also does so in the opposite direction. Therefore, in our estimation, we cluster our standard errors at the carrier-route-pair. In this way, we allow for correlation in the error terms among all observations for a carrier flying Jacksonville-Philadelphia or Philadelphia-Jacksonville (for example).

To capture the full effect of both the threat of entry, and the actual entry, by Southwest, we create three sets of entry dummy variables. First, because airlines may become aware of Southwest's expansion plans before they actually occur, we construct dummies to identify the quarters preceding the quarter in which Southwest enters the second endpoint airport of a route, and begins to threaten that route. In the above example, these dummy variables would identify the quarters preceding the fourth quarter of 2004. Second, we include a set of dummies to measure the period following the quarter in which Southwest establishes a presence in the second endpoint airport without offering service on the route. Third, we include a set of dummy variables to indicate the quarter of entry onto the route, i.e., the quarter in which Southwest begins offering nonstop service on the route, as well as subsequent quarters.

We examine data for the 12 quarters preceding the quarter in which Southwest enters the second endpoint airport and first threatens the route, the quarter in which Southwest establishes a presence in the second endpoint airport, and the 12 quarters following the quarter in which Southwest establishes a presence at the second endpoint airport. This yields 5200 carrier-routequarter observations for incumbent carriers on threatened routes. ${ }^{8}$

\footnotetext{
${ }^{8}$ Like Goolsbee and Syverson, we do not have 25 observations for many carrier-routes because of truncation at the start of the sample, and because, in some case, the airlines did not fly the route throughout the entire 25-quarter period.
} 


\subsection{Dependent Variables: On-Time Performance}

For our dependent variables, we initially consider the three most frequently cited measures of on-time performance. In published reports, the DOT generally defines a flight to be late if it arrives at the gate at least 15 minutes late. Hence, our first measure of on-time performance measures the proportion of carrier i's flights on route $r$ in quarter $q$ that arrives at least 15 minutes late. Our second measure places stricter requirements for characterizing a flight as late. Specifically, it measures the proportion of flights on route $r$ in quarter $q$ that arrives at least 30 minutes late. Finally, we also measure the average number of minutes late (or early) that carrier i's flights on route $\mathrm{r}$ in quarter $\mathrm{q}$ arrive at the gate, relative to its scheduled arrival time.

\subsection{Southwest's On-Time Performance Record}

A key point in our analysis is Southwest's superiority in on-time performance. To provide some evidence of this, Table 1 reports airline on-time performance rankings for each year in our sample. Among the major US carriers (on-time data is only gathered for US carriers with at least $1 \%$ of the domestic market), Southwest had the best on-time performance (lowest percentage of flights arriving at least 15 minutes late) every year from 1993-1999. During the next five years, it had somewhat less consistent superiority, though still generally strong performance: it was second in on-time performance in 2000, fell to fifth in 2001, returned to first place in 2002, fell to sixth place in 2003, and improved to second place in 2004. Overall, Southwest had the highest on-time arrival rate of any major US carrier between 1987 (when data were first collected) and 2004. These data strongly suggest that Southwest enjoyed lower marginal costs of on-time performance provision. They also suggest that Southwest would face greater adjustment costs in reducing its on-time performance, because of the substantial reputational costs it would incur.

\section{Estimation Strategy}

To examine whether airlines vary their on-time performance in response to the threat of, or actual, entry by Southwest, we estimate a set of fixed-effects models for the various measures of on-time performance described above, as well as some others that we introduce below. The variables of interest are the dummy variables indicating entry and entry threats by Southwest. In all models, we also include carrier-route fixed effects to control for unobserved differences across carriers and routes, and carrier-quarter fixed effects to control for any changes over time 
in the carrier's overall on-time performance. Because we include carrier-route fixed effects in all models, and because we omit dummy variables for the $9^{\text {th }}-12^{\text {th }}$ quarters preceding the quarter in which Southwest establishes a presence at the second endpoint airport, our estimated coefficients indicate the carrier's on-time performance in the dummy period relative to its performance in the period 2-3 years (9-12 quarters) prior to the quarter in which Southwest establishes a presence at the second endpoint airport, creating the threat of entry for the given route. As discussed above, in all models we cluster the standard errors at the carrier-route-pair level, to account for correlations in the standard errors. ${ }^{9}$

Our primary regression is the following:

$$
\begin{gathered}
y_{i j t}=\mu_{i j}+\delta_{i t}+T_{i j t}^{-78}+T_{i j t}^{-56}+T_{i j t}^{-34}+T_{i j t}^{-12}+T_{i j t}^{0}+T_{i j t}^{12}+T_{i j t}^{3+}+E_{i j t}^{0}+E_{i j t}^{12}+E_{i j t}^{3+} \\
+ \text { Load }_{i j t}+\text { DestFlights }_{i j t}+\text { OrigFlights }_{i j t}+\varepsilon_{i j t}
\end{gathered}
$$

Here, $y_{i j t}$ is one of the dependent variables described above (as well as scheduled flight time and travel time, as discussed below). The first two right-hand-side variables represent carrier-route and carrier-quarter fixed effects, respectively. Next, the T variables represent dummies that capture the proximity of that observation to the Southwest threat. For example, $\mathrm{T}^{-78}$ equals one if the observation occurred 7-8 quarters before Southwest threatened to enter, $\mathrm{T}^{-56}$ equals one if the observation occurred 5-6 quarters before Southwest threatened to enter ${ }^{10}$, etc. $\mathrm{T}^{0}$ indicates the quarter in which Southwest actually enters the second endpoint airport, threatening the route. $\mathrm{T}^{12}$ indicates the first two quarters after Southwest has threatened the route, but before Southwest has actually started offering service on the route, while $\mathrm{T}^{3+}$ indicates the 3rd-12th quarters after Southwest has threatened the route but not yet begun to fly on the route. Similarly, the E variables indicate the number of quarters since Southwest begins offering service; $\mathrm{E}^{0}$ indicates the quarter in which Southwest actually begins offering service on the route, $\mathrm{E}^{12}$ indicates the first two quarters after Southwest begins offering service, while $\mathrm{E}^{3+}$ indicates the 3rd-12th

\footnotetext{
${ }^{9}$ We also tried clustering the standard errors at the route-pair level, to allow for correlations across carriers on the same route-pair. This actually yielded generally small standard errors. Therefore we report the more conservative results, clustering by carrier-route-pair.

${ }^{10}$ We defined the dummy variables to measures two or more quarters, rather than following Goolsbee and Syverson in using single quarters, in order to obtain more robust estimates, that are less likely to be affected by unusual events in any one quarter. However, we obtain very similar results when we estimate our models defining the dummies in the same way as Goolsbee and Syverson.
} 
quarters after entry. Finally, we include three additional control variables. Load controls for the average load factor, while OrigFlights and DestFlights are counts of the number of flights at the origin and destination airports, respectively.

\section{Results}

In Table 2, we examine how incumbents’ arrival delays respond to entry and entry threats by Southwest. As can be seen, all three conventional measures of arrival delay indicate that incumbents' on-time performance worsens. Looking at the first two models, we see that the fraction of the incumbent's flights that arrive at least 15 (30) minutes late increases by about 6-9 (3-5) percentage points in the quarter when Southwest enters a route and in the quarters that follow entry. This is a very large effect given that, on average, 21 (10) percent of flights arrive at least 15 (30) minutes late. Similarly, in the third model, the average arrival delay increases by 34 minutes (from an average of 5.8 minutes) following entry by Southwest. Moreover, consistent with Goolsbee and Syverson (2008), the results in Table 2 indicate that airlines begin responding to the threat of entry before Southwest even threatens the route; incumbents' on-time performance begins to worsen before Southwest actually enters the second endpoint airport. Their arrival delays worsen further when Southwest enters the second endpoint airport (thus threatening the route) and even more when Southwest begins to offer flights on the route. ${ }^{11}$

It is difficult to say precisely when airlines begin responding to the threat of entry by Southwest. The results in Table 2 indicate that incumbents' on-time performance worsens as early as 7-8 quarters prior to Southwest threatening the route. However, the results show that delays in quarter 5-6 prior to Southwest threatening the route are no different from the omitted comparison period. The delays then begin increase again in quarters 3-4 prior to Southwest threatening the route, and generally increase in subsequent quarters. Thus, it appears that, consistent with Goolsbee and Syverson, the airlines generally begin to respond to the threat of entry 3-4 quarters before Southwest enters the second endpoint airport of a route.

\footnotetext{
${ }^{11}$ As noted in Section 2.1, the predictions for monopoly routes threatened by entry are clearest. Therefore, we also estimated the models in Table 1 using only the monopoly routes that Southwest threatened. These make up about $70 \%$ of our sample. The results for the monopoly routes are very similar to those reported for the full sample in Table 1.
} 
Importantly, as noted above, in these models (and in all other models below), we control for load factor and the number of flights at the endpoint airports. By controlling for Load $^{12}$, we preclude the possibility that our results are being driven by more crowded flights (yielding more delays), resulting from incumbents cutting prices in response to the threat of entry and actual entry by Southwest. Similarly, by controlling for OrigFlights and DestFlights, we can eliminate the possibility that greater congestion at the endpoint airports, resulting from Southwest entry, is driving the increase in delays that we observe.

Although these results provide strong evidence that airline delays increase in response to entry and entry threats by Southwest, they do not shed light on how this occurs. We explore this in columns 4 and 5. First, we consider the possibility that delays increase because incumbents begin shortening scheduled flight times as a way to retain customers, in anticipation of Southwest entering with shorter flight times. The results in column 4 show that airlines do have shorter scheduled flight times in all periods relative to the base period (9-12 quarters prior to threat). However, the effect is relatively small (generally less than one minute), usually statistically insignificant, and is very stable across time periods relative to entry and entry threats, unlike our results for our delay measures. Hence, this does not appear to be a viable explanation for the increases in arrival delays that we observe. ${ }^{13}$ Second, to further assess whether reductions in scheduled flight times could be driving the results reported in Table 2, we use a measure of delay, travel time, which is independent of the scheduled time for the flight. Travel time only measures the time from when the flight is scheduled to depart until the time that it actually arrives. In this way, it measures actual travel time plus the delay in departing the airport. It is unaffected by changes in the scheduled time for the flight. The results in column 5 show that travel time also worsened in response to entry and entry threats by Southwest; travel time increases by about 5-7 minutes following entry by Southwest. These results further verify that it was not simply shorter scheduled flight times that underlie the increase in arrival delays that we report in Table 2.

\footnotetext{
${ }^{12}$ We recognize that load factor may be endogenous in our models of on-time performance. Therefore, we also instrument for load factor using the carrier's average load factor on flights from other airports. The results are very similar; load factor has a positive and statistically significant effect, and the effects of entry and entry threats remain qualitatively unchanged. Based on these results, we can also exclude more crowded planes as an alternative explanation for our results.

${ }^{13}$ To verify this, we also reestimated the model of arrival delays controlling for the scheduled flight time. We obtain very similar results to those reported in column 3.
} 
In Table 3, we examine incumbents' response to entry and entry threats by an entrant with average on-time performance, Continental. The results show that incumbent arrival delays did not increase following entry by Continental, nor did they systematically increase prior to entry. If anything, these results show that incumbents reduced their travel time in response to entry by Continental. When compared to Table 2, these results provide strong evidence that the airlines responded differently to the arrival of Continental than they did to the arrival of Southwest. This is consistent with the argument derived in section 2 that most airlines, recognizing that they could not compete against Southwest on service, instead focused on cutting prices and costs in response to entry, and entry threats, by Southwest.

Next, we address two issues raised by Goolsbee and Syverson in their analysis. First, we consider whether our results are driven by our use of a three-year pre-threat window. To assess whether this choice is driving our results, we extend the pre-threat period to four years, and include dummies for quarters back to 12 quarters before Southwest threatens the route. This approach yields a one-year comparison period, quarters 13-16. We report these results in Table 4.

The pattern of results is very similar to those in Table 2, though the effects are not quite as strong or as statistically significant. Nonetheless, they provide additional evidence that incumbents offer worse on-time performance in the face of entry by Southwest. Moreover, the results in Table 4 clearly show that incumbents did not start responding to the threat of entry by Southwest more than two years before Southwest threatened to enter the market. The spike in incumbents' responses in the period 7-8 quarters before entry suggests that this result likely reflects some noise, and the results as a whole provide further support that incumbents likely began responding to the threat posed by Southwest's entry about one year before Southwest started serving both endpoint airports of the route.

Second, we consider whether our results reflect Southwest entering airports where service quality is worsening. To consider this possibility, we follow the strategy used by Goolsbee and Syverson, and control for incumbents' on-time performance on routes between a threatened airport and airports that Southwest does not serve. The idea is to use the incumbents' on-time performance on routes to and from airports not served by Southwest to control for other changes, unrelated to Southwest's imminent entry, at the threatened airports. For example, in the case of Southwest threatening to enter the Philadelphia-Jacksonville route, we would use the 
incumbent's on-time performance on flights between Philadelphia ${ }^{14}$ and other airports that Southwest does not serve, such as Laguardia, Boston, Reagan National, etc.

We report the results of this analysis in Table 5. Again, the results are very similar to those reported in Table 2. These results preclude the possibility that our findings are driven by unobserved changes in the airports that Southwest threatens. They provide more evidence that we are identifying the causal impact of entry and entry threats by Southwest on incumbent ontime performance.

In Table 6, we re-estimate our baseline models (Table 2), weighting each observation by the average number of passengers flying on the carrier's route during our sample period. These results provide a better assessment of the overall impact on passengers of incumbents' responses to the threat of entry by Southwest. The results are very similar to those in Table 2, though the coefficients are a little smaller. This suggests that incumbents may be a little more likely to compete with Southwest on larger routes; on smaller routes, the decision to reduce efforts in ontime performance may be easier.

In all of the above analyses, we include carrier-route and carrier-quarter fixed effects, in an effort to isolate the impact of the threat of, and actual entry. However, this approach imposes a cost, because it precludes an assessment of how airlines reorganize their operations and reallocate their resources and efforts over time, across routes, in response to entry by Southwest. To examine this issue, we reestimate our baseline models, including carrier, route, and quarter fixed effects (in place of carrier-quarter and carrier-route fixed effects). We report these results in Table 7.

The results in Table 7 generally show larger effects of entry and threat of entry than those reported in Table 2. The larger effects suggest that when airlines reduce their on-time performance efforts on routes threatened and entered by Southwest, they reallocate (some of) these resources and effort to their other routes that are not threatened by Southwest.

\footnotetext{
${ }^{14}$ We would also use incumbents' on-time performance on flights between Jacksonville and airports that Southwest does not serve, but when Southwest began serving Philadelphia, the other airlines serving the Jacksonville airport only flew to other airports served by Southwest. That is, incumbents were not flying between Jacksonville and any airports not served by Southwest.
} 


\section{Alternative measures of service quality}

Although this paper focuses on on-time performance, we recognize that airlines compete on other dimensions of service quality. We examine how airlines respond on some of these other dimensions of service quality when Southwest threatens and enters new routes. We report the results in Table 8. The results show that airlines do not increase the number of flights they cancel on routes threatened by Southwest entry, while they do increase the number of departures that they offer on these routes. These results suggest that airlines may respond differently on other aspects of service quality when responding to entry by Southwest. While increases in quality along other dimensions should not be surprising, these findings could raise some concerns about our results for on-time performance. We discuss these below.

Regarding cancellations, our findings indicate no reduction in service quality (no increase in cancellations) in response to entry. However, airlines cancel only about one percent of their flights in our sample, giving us much weaker identification power for this measure. Therefore, while airlines may think differently about cancellations than about on-time performance, it is difficult to draw meaningful conclusions from the cancellation results. Regarding number of flights offered, one might be concerned that the increase in the number of flights that carriers offer in response to entry and entry threats by Southwest may be driving our on-time performance results: Airlines increase their flight frequency, which causes greater delays. To investigate this possibility, we re-estimated our baseline models, controlling for the number of flights the airlines offered on the route. Our results remain virtually unchanged by the inclusion of this variable.

\section{Conclusion}

We examine whether entry and entry threats by Southwest Airlines cause incumbent airlines to improve their on-time performance as a way to protect their market share. Perhaps surprisingly, our results show that airlines did not improve on-time performance in response to Southwest; rather, incumbent on-time performance worsened. We argue that this finding can be consistent with a basic theoretical model of firms competing on price and quality, especially when the entrant has an advantage on the quality dimension being examined. We corroborate this intuition by showing empirically that firms are virtually unresponsive in on-time performance to entry and entry threats by a rival with more average quality, Continental. 
Our findings generate several key takeaways. First, they show that entry and entry threats by at least some airlines can cause incumbents to reduce their on-time performance as the firms move to a new equilibrium. Further, while prior theoretical and empirical work often suggests that average quality and competition are positively correlated, our results show that, even for an industry where this relationship appears to hold, it does not imply that each firm will improve its quality in response to new competition, or the threat of it. More broadly, our findings suggest that the welfare implications of entry, at least with regard to quality, can depend on the entrant and may involve the average consumer actually experiencing lower quality. 


\section{REFERENCES}

Aghion, P. \& Bolton, P. 1987. Contracts as a Barrier to Entry. American Economic Review. 77: 388-401.

Anderson, S. \& de Palma, A. 2001. Product Diversity in Asymmetric Oligopoly: Is the Quality of Consumer Goods Too Low? Journal of Industrial Economics. 49:113-135.

Bain, J. 1951. Relation of Profit Rate to Industry Concentration: American Manufacturing, 1936-1940. Quarterly Journal of Economics. 65: 293-324.

Banker, R., Khosla, I. \& Sinha, K. 1998. Quality and Competition. Management Science. 44: 1179-1192.

Ben-Akiva, M., De Palma, A. \& Thisse, J. 1989. Spatial Competition with Differentiated Products. Regional Science and Urban Economics. 19: 87-102.

Dafny, L. 2005. Games Hospitals Play: Entry Deterrence in Hospital Procedure Markets. Journal of Economics and Management Strategy. 14:513-542.

D’Aspremont, C. Gabszewicz, J. \& Thisse, J. 1979. Hotellings Stability in Competition. Econometrica. 47:1145-1150.

Dixit, A. 1979. A Model of Duopoly Suggesting a Theory of Entry Barriers. Bell Journal of Economics. 10: 20-32.

Domberger, S., Hall, C. \& Li, E. 1995. The Determinants of Price and Quality in Competitively Tendered Contracts. Economic Journal. 105: 1454-1470.

Domberger, S. \& Sherr, A. 1989. The Impact of Competition on Pricing and Quality of Legal Services. International Review of Law and Economics, 9, 41-56.

Economides, N., Seim, K. \& Viard, V. 2008. Quantifying the Benefits of Entry into Local Phone Service. RAND Journal of Economics. 39: 699-730.

Gal-Or, E. 1983. Quality and Quantity Competition. Bell Journal of Economics, 14: 590-600.

Goolsbee, A. \& Petrin, A. 2004. The Consumer Gains from Direct Broadcast Satellites and the Competition with Cable TV. Econometrica. 72:351-381.

Goolsbee, A., \& Syverson, C. 2008. How Do Incumbents Respond to the Threat of Entry? Evidence from the Major Airlines. Quarterly Journal of Economics. 123:1611-1633. 
Irmen, A. \& Thisse, J. 1998. Competition in Multi-characteristics Spaces: Hotelling was Almost Right. Journal of Economic Theory. 78: 76-102.

Ishibashi, I. \& Matsushima, N. The Existence of Low-End Firms May Help High-End Firms. Marketing Science. 28: 136-147.

Januszewski, S. 2004. The effect of air traffic delays on airline prices. Working paper. University of California, San Diego.

Mayer, C., \& Sinai, T. 2003. Network effects, congestion externalities, and air traffic delays: Or why not all delays are evil. American Economic Review, 93: 11941215.

Mazzeo, M. 2002. Product Choice and Oligopoly Market Structure. RAND Journal of Economics. 33:221-242.

Mazzeo, M. 2003. Competition and service quality in the US airline industry. Review of Industrial Organization, 22: 275-296.

Moorthy, S. 1988. Product and Price Competition in a Duopoly. Marketing Science. 7: 141-168.

Netz, J. \& Taylor, B. 2002. Maximum or Minimum Differentiation? Location Patterns of Retail Outlets. Review of Economics and Statistics. 84: 162-175.

Neven, D. \& Thisse, J. 1990. On Quality and Variety Competition. In Economic Decision-Making: Games, Econometrics and Optimisation (Gabszewicz, Richard, Wolsey, eds.), Amsterdam: North Holland.

Prince, J., \& Simon, D.H. 2009. Multimarket Contact and Service Quality: Evidence from On-Time Performance in the US Airline Industry. Academy of Management Journal. 52: 336-354.

Rupp, N., Owens, D., \& Plumly, L. 2003. Does competition influence airline on-time performance. In: Lee, D. (Ed.), Advances in airline economics: Competition policy and antitrust, vol. 1. Elsevier; Forthcoming.

Rupp, N. \& Holmes, G. 2006. An Investigation into the Determinants of Flight Cancellations. Economica. 73:749-783.

Schmalensee, R. 1974. Market Structure, Durability, and Maintenance Effort. Review of Economic Studies, 41: 277-287.

Schmalensee, R. 1979. Market Structure, Durability, and Quality - Selective Survey. Economic Inquiry, 17: 177-196. 
Swan, P. 1970. Durability of Consumption Goods. American Economic Review, 60: 884-894.

Tirole, J. 2000. The Theory of Industrial Organization. MIT Press.

Vandenbosch M. \& Weinberg, C. 1995. Product and Price-Competition in a 2-Dimensional Vertical Differentiation Model. Marketing Science. 14:224-249. 


\section{TABLES}

Table 1

Airline On-Time Rankings, 1993-2004 (Percentage of flights arriving less than 15 minutes late)

\begin{tabular}{|l|l|l|l|l|l|l|l|l|l|l|l|l|}
\hline 1993 & 1994 & 1995 & 1996 & 1997 & 1998 & 1999 & 2000 & 2001 & 2002 & 2003 & 2004 & $\begin{array}{l}1987- \\
2004\end{array}$ \\
\hline WN & WN & WN & WN & WN & WN & WN & TW & CO & WN & UA & OO & WN \\
\hline HP & NW & NW & NW & CO & TW & AA & WN & NW & TW & AA & WN & NW \\
\hline NW & HP & AS & US & NW & US & DL & NW & TW & CO & CO & B6 & AA \\
\hline AS & AS & UA & CO & US & AA & US & DL & DL & NW & US & UA & CO \\
\hline TW & US & AA & UA & UA & CO & TW & CO & WN & US & HP & NW & HP \\
\hline AA & TW & HP & HP & AA & HP & CO & UA & AA & DL & WN & DL & US \\
\hline UA & AA & DL & AA & DL & UA & UA & AA & US & AA & NW & CO & DL \\
\hline US & CO & TW & AS & HP & NW & AS & US & AS & HP & DL & HP & AS \\
\hline DL & UA & US & DL & AS & DL & NW & AS & HP & UA & MQ & AA & UA \\
\hline CO & DL & CO & TW & TW & AS & HP & HP & UA & MQ & AS & AS & MQ \\
\hline
\end{tabular}

We report the top ten carriers in each year. For every year except 2002 and 2004, this comprises all reporting airlines. 
Table 2

Incumbents' on-time performance response to entry and entry threats by Southwest

\begin{tabular}{|c|c|c|c|c|c|}
\hline & $\begin{array}{l}\text { Proportion of } \\
\text { flights arriving } \\
\text { at least } 15 \\
\text { minutes late } \\
\end{array}$ & $\begin{array}{l}\text { Proportion of } \\
\text { flights arriving } \\
\text { at least } 30 \\
\text { minutes late } \\
\end{array}$ & $\begin{array}{l}\text { Arrival delay } \\
\text { (minutes) }\end{array}$ & $\begin{array}{l}\text { Scheduled } \\
\text { flight time }\end{array}$ & Travel time \\
\hline $\begin{array}{l}\text { 7-8 quarters } \\
\text { before } \\
\text { Southwest } \\
\text { threatens route }\end{array}$ & $\begin{array}{l}0.038 \\
(0.014)^{* *}\end{array}$ & $\begin{array}{l}0.022 \\
(0.009)^{*}\end{array}$ & $\begin{array}{l}2.24 \\
(0.665)^{* *}\end{array}$ & $\begin{array}{l}-1.053 \\
(0.275)^{* *}\end{array}$ & $\begin{array}{l}2.860 \\
(0.935)^{* *}\end{array}$ \\
\hline $\begin{array}{l}5-6 \text { quarters } \\
\text { before } \\
\text { Southwest } \\
\text { threatens route }\end{array}$ & $\begin{array}{l}0.018 \\
(0.012)\end{array}$ & $\begin{array}{l}0.002 \\
(0.008)\end{array}$ & $\begin{array}{l}1.120 \\
(0.633)+\end{array}$ & $\begin{array}{l}-0.926 \\
(0.369)^{*}\end{array}$ & $\begin{array}{l}1.610 \\
(0.862)+\end{array}$ \\
\hline $\begin{array}{l}\text { 3-4 quarters } \\
\text { before } \\
\text { Southwest } \\
\text { threatens route }\end{array}$ & $\begin{array}{l}0.045 \\
(0.014)^{* *}\end{array}$ & $\begin{array}{l}0.023 \\
(0.009)^{*}\end{array}$ & $\begin{array}{l}2.342 \\
(0.735)^{* *}\end{array}$ & $\begin{array}{l}-0.667 \\
(0.400)+\end{array}$ & $\begin{array}{l}3.645 \\
(0.970)^{* *}\end{array}$ \\
\hline $\begin{array}{l}1-2 \text { quarters } \\
\text { before } \\
\text { Southwest } \\
\text { threatens route }\end{array}$ & $\begin{array}{l}0.048 \\
(0.015)^{* *}\end{array}$ & $\begin{array}{l}0.027 \\
(0.009)^{* *}\end{array}$ & $\begin{array}{l}2.520 \\
(0.781)^{* *}\end{array}$ & $\begin{array}{l}-0.761 \\
(0.487)\end{array}$ & $\begin{array}{l}3.612 \\
(1.079)^{* *}\end{array}$ \\
\hline $\begin{array}{l}\text { Southwest } \\
\text { threatens route }\end{array}$ & $\begin{array}{l}0.051 \\
(0.018)^{* *}\end{array}$ & $\begin{array}{l}0.019 \\
(0.011)+\end{array}$ & $\begin{array}{l}2.604 \\
(0.951)^{* *}\end{array}$ & $\begin{array}{l}-0.782 \\
(0.522)\end{array}$ & $\begin{array}{l}4.777 \\
(1.271)^{* *}\end{array}$ \\
\hline $\begin{array}{l}1-2 \text { quarters } \\
\text { after Southwest } \\
\text { threatens route } \\
\text { (no flights) }\end{array}$ & $\begin{array}{l}0.047 \\
(0.018)^{* *}\end{array}$ & $\begin{array}{l}0.027 \\
(0.011)^{*}\end{array}$ & $\begin{array}{l}2.257 \\
(1.011)^{*}\end{array}$ & $\begin{array}{l}-0.673 \\
(0.568)\end{array}$ & $\begin{array}{l}3.371 \\
(1.275)^{* *}\end{array}$ \\
\hline $\begin{array}{l}\text { 3-12 quarters } \\
\text { after Southwest } \\
\text { threatens route } \\
\text { (no flights) }\end{array}$ & $\begin{array}{l}0.073 \\
(0.020)^{* *}\end{array}$ & $\begin{array}{l}0.040 \\
(0.012)^{* *}\end{array}$ & $\begin{array}{l}3.674 \\
(1.100)^{* *}\end{array}$ & $\begin{array}{l}-0.562 \\
(0.669)\end{array}$ & $\begin{array}{l}5.131 \\
(1.432)^{* *}\end{array}$ \\
\hline $\begin{array}{l}\text { Southwest } \\
\text { begins flying } \\
\text { route }\end{array}$ & $\begin{array}{l}0.062 \\
(0.020)^{* *}\end{array}$ & $\begin{array}{l}0.030 \\
(0.013)^{*}\end{array}$ & $\begin{array}{l}3.310 \\
(1.096)^{* *}\end{array}$ & $\begin{array}{l}-0.756 \\
(0.639)\end{array}$ & $\begin{array}{l}4.645 \\
(1.439)^{* *}\end{array}$ \\
\hline $\begin{array}{l}\text { 1-2 quarters } \\
\text { after Southwest } \\
\text { enters route }\end{array}$ & $\begin{array}{l}0.077 \\
(0.022)^{* *}\end{array}$ & $\begin{array}{l}0.039 \\
(0.013)^{* *}\end{array}$ & $\begin{array}{l}3.364 \\
(1.158)^{* *}\end{array}$ & $\begin{array}{l}-0.742 \\
(0.745)\end{array}$ & $\begin{array}{l}5.791 \\
(1.642)^{* *}\end{array}$ \\
\hline $\begin{array}{l}\text { 3-12 quarters } \\
\text { after Southwest } \\
\text { enters route }\end{array}$ & $\begin{array}{l}0.086 \\
(0.023)^{* *}\end{array}$ & $\begin{array}{l}0.049 \\
(0.015)^{* *}\end{array}$ & $\begin{array}{l}4.182 \\
(1.295)^{* *}\end{array}$ & $\begin{array}{l}-0.773 \\
(0.779)\end{array}$ & $\begin{array}{l}6.915 \\
(1.756)^{* *}\end{array}$ \\
\hline Load factor & $\begin{array}{l}0.170 \\
(.036)^{* *}\end{array}$ & $\begin{array}{l}0.078 \\
(0.024)^{* *}\end{array}$ & $\begin{array}{l}10.492 \\
(1.745)^{* *}\end{array}$ & $\begin{array}{l}-1.524 \\
(0.898)+\end{array}$ & $\begin{array}{l}9.258 \\
(2.216)^{* *}\end{array}$ \\
\hline $\begin{array}{l}\text { Flights arriving } \\
\text { at destination } \\
\text { airport during } \\
\text { same hour }\end{array}$ & $\begin{array}{l}0.006 \\
(0.027)\end{array}$ & $\begin{array}{l}-0.022 \\
(0.016)\end{array}$ & $\begin{array}{l}0.753 \\
(1.240)\end{array}$ & $\begin{array}{l}1.236 \\
(0.912)\end{array}$ & $\begin{array}{l}3.586 \\
(1.861)+\end{array}$ \\
\hline $\begin{array}{l}\text { Flights departing } \\
\text { from origination } \\
\text { airport during } \\
\text { same hour }\end{array}$ & $\begin{array}{l}-0.014 \\
(0.026)\end{array}$ & $\begin{array}{l}-0.027 \\
(0.017)\end{array}$ & $\begin{array}{l}-1.266 \\
(1.561)\end{array}$ & $\begin{array}{l}-2.950 \\
(0.887)^{* *}\end{array}$ & $\begin{array}{l}-2.586 \\
(2.196)\end{array}$ \\
\hline
\end{tabular}




\begin{tabular}{|l|l|l|l|l|l|}
\hline & & & & & \\
\hline $\mathrm{N}$ & 5200 & 5200 & 5188 & 5188 & 5188 \\
\hline
\end{tabular}

All models include carrier-route and carrier-quarter fixed effects. Standard errors clustered by carrier-route-pair are reported in parentheses. Models 1 and 2 are marginal effects from fractional logit models, estimated using maximum likelihood, to account for the proportional nature of the dependent variable (Papke \& Wooldridge, 1996).

$\dagger p<.10$

$* p<.05$

$* * p<.01$ 
Table 3

Incumbents' on-time performance response to entry and entry threats by Continental

\begin{tabular}{|c|c|c|c|c|c|}
\hline & $\begin{array}{l}\text { Proportion of } \\
\text { flights arriving at } \\
\text { least } 15 \text { minutes } \\
\text { late }\end{array}$ & $\begin{array}{l}\text { Proportion of } \\
\text { flights arriving } \\
\text { at least } 30 \\
\text { minutes late }\end{array}$ & $\begin{array}{l}\text { Arrival delay } \\
\text { (minutes) }\end{array}$ & $\begin{array}{l}\text { Scheduled } \\
\text { flight time }\end{array}$ & Travel time \\
\hline $\begin{array}{l}\text { 7-8 quarters } \\
\text { before } \\
\text { Continental } \\
\text { threatens route }\end{array}$ & $\begin{array}{l}-0.008 \\
(0.011)\end{array}$ & $\begin{array}{l}-0.027 \\
(0.009)^{* *}\end{array}$ & $\begin{array}{l}0.506 \\
(0.532)\end{array}$ & $\begin{array}{l}-0.607 \\
(0.372)\end{array}$ & $\begin{array}{l}-0.165 \\
(1.059)\end{array}$ \\
\hline $\begin{array}{l}5-6 \text { quarters } \\
\text { before } \\
\text { Continental } \\
\text { threatens route }\end{array}$ & $\begin{array}{l}0.006 \\
(0.023)\end{array}$ & $\begin{array}{l}-0.001 \\
(0.016)\end{array}$ & $\begin{array}{l}0.410 \\
(1.143)\end{array}$ & $\begin{array}{l}-0.515 \\
(0.512)\end{array}$ & $\begin{array}{l}-2.389 \\
(1.761)\end{array}$ \\
\hline $\begin{array}{l}\text { 3-4 quarters } \\
\text { before } \\
\text { Continental } \\
\text { threatens route }\end{array}$ & $\begin{array}{l}0.012 \\
(0.019)\end{array}$ & $\begin{array}{l}-0.021 \\
(0.015)\end{array}$ & $\begin{array}{l}0.272 \\
(1.210)\end{array}$ & $\begin{array}{l}-1.074 \\
(0.667)\end{array}$ & $\begin{array}{l}-3.616 \\
(1.875)+\end{array}$ \\
\hline $\begin{array}{l}1-2 \text { quarters } \\
\text { before } \\
\text { Continental } \\
\text { threatens route }\end{array}$ & $\begin{array}{l}0.010 \\
(0.020) \\
\end{array}$ & $\begin{array}{l}0.006 \\
(0.010)\end{array}$ & $\begin{array}{l}0.780 \\
(0.872)\end{array}$ & $\begin{array}{l}-0.762 \\
(0.387)^{*}\end{array}$ & $\begin{array}{l}-2.530 \\
(1.308)+\end{array}$ \\
\hline $\begin{array}{l}\text { Continental } \\
\text { threatens route }\end{array}$ & $\begin{array}{l}0.055 \\
(0.014)^{* *}\end{array}$ & $\begin{array}{l}0.016 \\
(0.015)\end{array}$ & $\begin{array}{l}2.128 \\
(0.940)^{*}\end{array}$ & $\begin{array}{l}0.355 \\
(0.312)\end{array}$ & $\begin{array}{l}0.562 \\
(1.298)\end{array}$ \\
\hline $\begin{array}{l}1-2 \text { quarters } \\
\text { after } \\
\text { Continental } \\
\text { threatens route } \\
\text { (no flights) }\end{array}$ & $\begin{array}{l}0.047 \\
(0.028)+\end{array}$ & $\begin{array}{l}0.012 \\
(0.015)\end{array}$ & $\begin{array}{l}2.414 \\
(1.568)\end{array}$ & $\begin{array}{l}-0.439 \\
(0.659)\end{array}$ & $\begin{array}{l}0.087 \\
(1.641)\end{array}$ \\
\hline $\begin{array}{l}\text { 3-12 quarters } \\
\text { after } \\
\text { Continental } \\
\text { threatens route } \\
\text { (no flights) }\end{array}$ & $\begin{array}{l}0.013 \\
(0.035)\end{array}$ & $\begin{array}{l}-0.016 \\
(0.019)\end{array}$ & $\begin{array}{l}0.552 \\
(2.134)\end{array}$ & $\begin{array}{l}-0.439 \\
(0.862)\end{array}$ & $\begin{array}{l}-2.018 \\
(2.609)\end{array}$ \\
\hline $\begin{array}{l}\text { Continental } \\
\text { begins flying } \\
\text { route }\end{array}$ & $\begin{array}{l}0.052 \\
(0.052)\end{array}$ & $\begin{array}{l}-0.004 \\
(0.024)\end{array}$ & $\begin{array}{l}3.446 \\
(1.966)+\end{array}$ & $\begin{array}{l}-2.105 \\
(1.076)^{*}\end{array}$ & $\begin{array}{l}-2.152 \\
(2.837)\end{array}$ \\
\hline $\begin{array}{l}1-2 \text { quarters } \\
\text { after } \\
\text { Continental } \\
\text { enters route } \\
\end{array}$ & $\begin{array}{l}-0.035 \\
(0.040)\end{array}$ & $\begin{array}{l}-0.029 \\
(0.019)\end{array}$ & $\begin{array}{l}-0.382 \\
(1.972)\end{array}$ & $\begin{array}{l}-1.104 \\
(1.161)\end{array}$ & $\begin{array}{l}-4.956 \\
(2.611)+\end{array}$ \\
\hline $\begin{array}{l}\text { 3-12 quarters } \\
\text { after } \\
\text { Continental } \\
\text { enters route }\end{array}$ & $\begin{array}{l}-0.004 \\
(0.034)\end{array}$ & $\begin{array}{l}-0.017 \\
(0.019)\end{array}$ & $\begin{array}{l}0.834 \\
(2.112)\end{array}$ & $\begin{array}{l}-2.919 \\
(1.598)+\end{array}$ & $\begin{array}{l}-5.121 \\
(3.009)+\end{array}$ \\
\hline Load factor & $\begin{array}{l}0.153 \\
(0.073)^{*}\end{array}$ & $\begin{array}{l}0.090 \\
(0.052)+\end{array}$ & $\begin{array}{l}10.632 \\
(5.077)^{*}\end{array}$ & $\begin{array}{l}6.815 \\
(2.842)^{*}\end{array}$ & $\begin{array}{l}21.122 \\
(9.024)^{*}\end{array}$ \\
\hline $\begin{array}{l}\text { Flights arriving } \\
\text { at destination } \\
\text { airport }\end{array}$ & $\begin{array}{l}0.042 \\
(0.023)\end{array}$ & $\begin{array}{l}0.010 \\
(0.016)\end{array}$ & $\begin{array}{l}2.205 \\
(1.465)\end{array}$ & $\begin{array}{l}2.472 \\
(1.629)\end{array}$ & $\begin{array}{l}5.293 \\
(2.361)^{*}\end{array}$ \\
\hline $\begin{array}{l}\text { Flights } \\
\text { departing from }\end{array}$ & $\begin{array}{l}-0.015 \\
(0.030)\end{array}$ & $\begin{array}{l}0.027 \\
(0.021)\end{array}$ & $\begin{array}{l}-0.042 \\
(1.534)\end{array}$ & $\begin{array}{l}0.632 \\
(1.650)\end{array}$ & $\begin{array}{l}0.947 \\
(2.083)\end{array}$ \\
\hline
\end{tabular}




\begin{tabular}{|l|l|l|l|l|l|}
\hline $\begin{array}{l}\text { origination } \\
\text { airport }\end{array}$ & & & & & \\
\hline $\mathrm{N}$ & & & & & \\
\hline
\end{tabular}

All models include carrier-route and carrier-quarter fixed effects. Standard errors clustered by carrier-route-pair are reported in parentheses. Models 1 and 2 are marginal effects from fractional logit models, estimated using maximum likelihood, to account for the proportional nature of the dependent variable (Papke \& Wooldridge, 1996).

$\dagger p<.10$

$* p<.05$

$* * p<.01$ 
Table 4

Incumbents' on-time performance response to entry and entry threats by Southwest, using a longer prethreat window

\begin{tabular}{|c|c|c|c|c|c|}
\hline & $\begin{array}{l}\text { Proportion of } \\
\text { flights arriving } \\
\text { at least } 15 \\
\text { minutes late }\end{array}$ & $\begin{array}{l}\text { Proportion of } \\
\text { flights arriving } \\
\text { at least } 30 \\
\text { minutes late }\end{array}$ & $\begin{array}{l}\text { Arrival delay } \\
\text { (minutes) }\end{array}$ & $\begin{array}{l}\text { Scheduled } \\
\text { flight time }\end{array}$ & Travel time \\
\hline $\begin{array}{l}\text { 11-12 quarters } \\
\text { before } \\
\text { Southwest } \\
\text { threatens route }\end{array}$ & $\begin{array}{l}-0.004 \\
(0.011)\end{array}$ & $\begin{array}{l}-0.007 \\
(0.008)\end{array}$ & $\begin{array}{l}-0.201 \\
(0.671)\end{array}$ & $\begin{array}{l}0.719 \\
(0.361)^{*}\end{array}$ & $\begin{array}{l}-0.459 \\
(1.079)\end{array}$ \\
\hline $\begin{array}{l}\text { 9-10 quarters } \\
\text { before } \\
\text { Southwest } \\
\text { threatens route }\end{array}$ & $\begin{array}{l}-0.005 \\
(0.016)\end{array}$ & $\begin{array}{l}-0.005 \\
(0.009)\end{array}$ & $\begin{array}{l}-0.216 \\
(0.815)\end{array}$ & $\begin{array}{l}0.008 \\
(0.435)\end{array}$ & $\begin{array}{l}-1.462 \\
(0.999)\end{array}$ \\
\hline $\begin{array}{l}\text { 7-8 quarters } \\
\text { before } \\
\text { Southwest } \\
\text { threatens route }\end{array}$ & $\begin{array}{l}0.034 \\
(0.014)^{*}\end{array}$ & $\begin{array}{l}0.018 \\
(0.011)+\end{array}$ & $\begin{array}{l}2.014 \\
(0.816)^{*}\end{array}$ & $\begin{array}{l}-0.694 \\
(0.451)\end{array}$ & $\begin{array}{l}1.741 \\
(1.103)\end{array}$ \\
\hline $\begin{array}{l}\text { 5-6 quarters } \\
\text { before } \\
\text { Southwest } \\
\text { threatens route }\end{array}$ & $\begin{array}{l}0.016 \\
(0.016)\end{array}$ & $\begin{array}{l}-0.002 \\
(0.011)\end{array}$ & $\begin{array}{l}1.097 \\
(1.036)\end{array}$ & $\begin{array}{l}-0.626 \\
(0.544)\end{array}$ & $\begin{array}{l}0.618 \\
(1.212)\end{array}$ \\
\hline $\begin{array}{l}\text { 3-4 quarters } \\
\text { before } \\
\text { Southwest } \\
\text { threatens route }\end{array}$ & $\begin{array}{l}0.041 \\
(0.019)^{*}\end{array}$ & $\begin{array}{l}0.019 \\
(0.012)\end{array}$ & $\begin{array}{l}2.150 \\
(1.136)+\end{array}$ & $\begin{array}{l}-0.416 \\
(0.577)\end{array}$ & $\begin{array}{l}2.443 \\
(1.354)+\end{array}$ \\
\hline $\begin{array}{l}\text { 1-2 quarters } \\
\text { before } \\
\text { Southwest } \\
\text { threatens route }\end{array}$ & $\begin{array}{l}0.044 \\
(0.018)^{*}\end{array}$ & $\begin{array}{l}0.022 \\
(0.012)\end{array}$ & $\begin{array}{l}2.319 \\
(1.160)^{*}\end{array}$ & $\begin{array}{l}-0.531 \\
(0.671)\end{array}$ & $\begin{array}{l}2.357 \\
(1.438)\end{array}$ \\
\hline $\begin{array}{l}\text { Southwest } \\
\text { threatens route }\end{array}$ & $\begin{array}{l}0.048 \\
(0.021)^{*}\end{array}$ & $\begin{array}{l}0.014 \\
(0.014)\end{array}$ & $\begin{array}{l}2.437 \\
(1.338)+\end{array}$ & $\begin{array}{l}-0.574 \\
(0.705)\end{array}$ & $\begin{array}{l}3.525 \\
(1.686)^{*}\end{array}$ \\
\hline $\begin{array}{l}1-2 \text { quarters after } \\
\text { Southwest } \\
\text { threatens route } \\
\text { (no flights) }\end{array}$ & $\begin{array}{l}0.044 \\
(0.022)^{*}\end{array}$ & $\begin{array}{l}0.023 \\
(0.014)\end{array}$ & $\begin{array}{l}2.118 \\
(1.413)\end{array}$ & $\begin{array}{l}-0.469 \\
(0.762)\end{array}$ & $\begin{array}{l}2.159 \\
(1.687)\end{array}$ \\
\hline $\begin{array}{l}\text { 3-12 quarters } \\
\text { after Southwest } \\
\text { threatens route } \\
\text { (no flights) }\end{array}$ & $\begin{array}{l}0.070 \\
(0.023) * *\end{array}$ & $\begin{array}{l}0.035 \\
(0.015)\end{array}$ & $\begin{array}{l}3.534 \\
(1.496)^{*}\end{array}$ & $\begin{array}{l}-0.383 \\
(0.861)\end{array}$ & $\begin{array}{l}3.821 \\
(1.859)^{*}\end{array}$ \\
\hline $\begin{array}{l}\text { Southwest } \\
\text { begins flying } \\
\text { route }\end{array}$ & $\begin{array}{l}0.059 \\
(0.024)^{*}\end{array}$ & $\begin{array}{l}0.026 \\
(0.016)\end{array}$ & $\begin{array}{l}3.169 \\
(1.481)^{*}\end{array}$ & $\begin{array}{l}-0.557 \\
(0.821)\end{array}$ & $\begin{array}{l}3.312 \\
(1.867)+\end{array}$ \\
\hline $\begin{array}{l}\text { 1-2 quarters after } \\
\text { Southwest enters } \\
\text { route }\end{array}$ & $\begin{array}{l}0.074 \\
(0.026)^{* *}\end{array}$ & $\begin{array}{l}0.034 \\
(0.017)\end{array}$ & $\begin{array}{l}3.212 \\
(1.530)^{*}\end{array}$ & $\begin{array}{l}-0.558 \\
(0.879)\end{array}$ & $\begin{array}{l}4.406 \\
(2.101)^{*}\end{array}$ \\
\hline $\begin{array}{l}\text { 3-12 quarters } \\
\text { after Southwest } \\
\text { enters route }\end{array}$ & $\begin{array}{l}0.084 \\
(0.026) * *\end{array}$ & $\begin{array}{l}0.045 \\
(0.018)^{*}\end{array}$ & $\begin{array}{l}4.042 \\
(1.699)^{*}\end{array}$ & $\begin{array}{l}-0.604 \\
(0.977)\end{array}$ & $\begin{array}{l}5.523 \\
(2.257)^{*}\end{array}$ \\
\hline Load factor & $\begin{array}{l}0.174 \\
(0.035)^{* *}\end{array}$ & $\begin{array}{l}0.082 \\
(0.023)^{* *}\end{array}$ & $\begin{array}{l}10.846 \\
(1.750)^{* *}\end{array}$ & $\begin{array}{l}-1.476 \\
(0.894)+\end{array}$ & $\begin{array}{l}9.703 \\
(2.224)^{* *}\end{array}$ \\
\hline
\end{tabular}




\begin{tabular}{|l|l|l|l|l|l|}
\hline $\begin{array}{l}\text { Flights arriving } \\
\text { at destination } \\
\text { airport }\end{array}$ & $\begin{array}{l}0.002 \\
(0.027)\end{array}$ & $\begin{array}{l}-0.022 \\
(0.015)\end{array}$ & $\begin{array}{l}0.539 \\
(1.200)\end{array}$ & $\begin{array}{l}1.411 \\
(0.872)\end{array}$ & $\begin{array}{l}3.390 \\
(1.832)+\end{array}$ \\
\hline $\begin{array}{l}\text { Flights departing } \\
\text { from origination } \\
\text { airport }\end{array}$ & $\begin{array}{l}-0.017 \\
(0.025)\end{array}$ & $\begin{array}{l}-0.026 \\
(0.016)+\end{array}$ & $\begin{array}{l}-1.255 \\
(1.505)\end{array}$ & $\begin{array}{l}-3.213 \\
(0.872)^{* *}\end{array}$ & $\begin{array}{l}-3.253 \\
(2.166)\end{array}$ \\
\hline $\mathrm{N}$ & & & & & \\
\hline
\end{tabular}

All models include carrier-route and carrier-quarter fixed effects. Standard errors clustered by carrier-route-pair are reported in parentheses. Models 1 and 2 are marginal effects from fractional logit models, estimated using maximum likelihood, to account for the proportional nature of the dependent variable (Papke \& Wooldridge, 1996).

$\dagger p<.10$

$* p<.05$

$* * p<.01$ 
Table 5

Incumbents' on-time performance response to entry and entry threats by Southwest, controlling for airport selection

\begin{tabular}{|c|c|c|c|c|c|}
\hline & $\begin{array}{l}\text { Proportion of } \\
\text { flights arriving } \\
\text { at least } 15 \\
\text { minutes late }\end{array}$ & $\begin{array}{l}\text { Proportion of } \\
\text { flights arriving } \\
\text { at least } 30 \\
\text { minutes late }\end{array}$ & $\begin{array}{l}\text { Arrival delay } \\
\text { (minutes) }\end{array}$ & $\begin{array}{l}\text { Scheduled } \\
\text { flight time }\end{array}$ & Travel time \\
\hline $\begin{array}{l}\text { OTP measure for } \\
\text { non-SW routes } \\
\text { from origin } \\
\text { airport }\end{array}$ & $\begin{array}{r}0.158 \\
(0.033)^{* *}\end{array}$ & $\begin{array}{r}0.069 \\
(0.030)^{*}\end{array}$ & $\begin{array}{r}0.184 \\
(0.034)^{* *}\end{array}$ & $\begin{array}{r}0.022 \\
(0.009)^{*}\end{array}$ & $\begin{array}{r}0.058 \\
(0.018)^{* *}\end{array}$ \\
\hline $\begin{array}{l}\text { OTP measure for } \\
\text { non-SW routes } \\
\text { from origin } \\
\text { airport }\end{array}$ & $\begin{array}{r}0.156 \\
(0.037)^{* *}\end{array}$ & $\begin{array}{r}0.110 \\
(0.031)^{* *}\end{array}$ & $\begin{array}{r}0.171 \\
(0.035)^{* *}\end{array}$ & $\begin{array}{r}0.011 \\
(0.015)\end{array}$ & $\begin{array}{r}0.044 \\
(0.019)^{*}\end{array}$ \\
\hline $\begin{array}{l}7-8 \text { quarters } \\
\text { before } \\
\text { Southwest } \\
\text { threatens route }\end{array}$ & $\begin{array}{r}0.027 \\
(0.016)^{*}\end{array}$ & $\begin{array}{r}0.014 \\
(0.010)\end{array}$ & $\begin{array}{r}1.657 \\
(0.735)^{*}\end{array}$ & $\begin{array}{r}-1.021 \\
(0.323)^{* *}\end{array}$ & $\begin{array}{r}2.617 \\
(1.102)^{*}\end{array}$ \\
\hline $\begin{array}{l}\text { 5-6 quarters } \\
\text { before } \\
\text { Southwest } \\
\text { threatens route }\end{array}$ & $\begin{array}{r}0.009 \\
(0.015)\end{array}$ & $\begin{array}{r}-0.002 \\
(0.010)\end{array}$ & $\begin{array}{r}0.616 \\
(0.851)\end{array}$ & $\begin{array}{r}-0.521 \\
(0.455)\end{array}$ & $\begin{array}{r}1.822 \\
(1.231)\end{array}$ \\
\hline $\begin{array}{l}\text { 3-4 quarters } \\
\text { before } \\
\text { Southwest } \\
\text { threatens route }\end{array}$ & $\begin{array}{r}0.042 \\
(0.018)^{*}\end{array}$ & $\begin{array}{r}0.027 \\
(0.013)^{*}\end{array}$ & $\begin{array}{r}1.664 \\
(0.991)+\end{array}$ & $\begin{array}{l}-0.423 \\
(0.569)\end{array}$ & $\begin{array}{r}4.239 \\
(1.359)^{* *}\end{array}$ \\
\hline $\begin{array}{l}\text { 1-2 quarters } \\
\text { before } \\
\text { Southwest } \\
\text { threatens route }\end{array}$ & $\begin{array}{r}0.042 \\
(0.020)^{*}\end{array}$ & $\begin{array}{r}0.027 \\
(0.012)^{*}\end{array}$ & $\begin{array}{r}2.042 \\
(1.052)+\end{array}$ & $\begin{array}{r}-0.522 \\
(0.704)\end{array}$ & $\begin{array}{r}5.003 \\
(1.567)^{* *}\end{array}$ \\
\hline $\begin{array}{l}\text { Southwest } \\
\text { threatens route }\end{array}$ & $\begin{array}{r}0.028 \\
(0.021) \\
\end{array}$ & $\begin{array}{r}0.012 \\
(0.015) \\
\end{array}$ & $\begin{array}{r}0.910 \\
(1.208) \\
\end{array}$ & $\begin{array}{r}-0.482 \\
(0.795)\end{array}$ & $\begin{array}{r}4.970 \\
(1.721)^{* *} \\
\end{array}$ \\
\hline $\begin{array}{l}\text { 1-2 quarters after } \\
\text { Southwest } \\
\text { threatens route } \\
\text { (no flights) }\end{array}$ & $\begin{array}{r}0.044 \\
(0.023)+\end{array}$ & $\begin{array}{r}0.027 \\
(0.015)+\end{array}$ & $\begin{array}{r}1.737 \\
(1.375)\end{array}$ & $\begin{array}{r}-0.570 \\
(0.839)\end{array}$ & $\begin{array}{r}4.290 \\
(1.715)^{*}\end{array}$ \\
\hline $\begin{array}{l}3-12 \text { quarters } \\
\text { after Southwest } \\
\text { threatens route } \\
\text { (no flights) }\end{array}$ & $\begin{array}{r}0.057 \\
(0.025)^{*}\end{array}$ & $\begin{array}{r}0.039 \\
(0.015)^{* *}\end{array}$ & $\begin{array}{r}2.352 \\
(1.458)\end{array}$ & $\begin{array}{r}-0.291 \\
(0.970)\end{array}$ & $\begin{array}{r}5.040 \\
(1.893)^{* *}\end{array}$ \\
\hline $\begin{array}{l}\text { Southwest } \\
\text { begins flying } \\
\text { route }\end{array}$ & $\begin{array}{r}0.039 \\
(0.027)\end{array}$ & $\begin{array}{r}0.024 \\
(0.017)\end{array}$ & $\begin{array}{r}1.889 \\
(1.484)\end{array}$ & $\begin{array}{r}-0.342 \\
(0.952)\end{array}$ & $\begin{array}{r}4.982 \\
(1.991)^{*}\end{array}$ \\
\hline $\begin{array}{l}\text { 1-2 quarters after } \\
\text { Southwest enters } \\
\text { route }\end{array}$ & $\begin{array}{r}0.055 \\
(0.027)^{*}\end{array}$ & $\begin{array}{r}0.032 \\
(0.017)+\end{array}$ & $\begin{array}{r}1.731 \\
(1.478)\end{array}$ & $\begin{array}{r}-0.295 \\
(1.019)\end{array}$ & $\begin{array}{r}6.078 \\
(2.272)^{* *}\end{array}$ \\
\hline $\begin{array}{l}\text { 3-12 quarters } \\
\text { after Southwest } \\
\text { enters route }\end{array}$ & $\begin{array}{r}0.074 \\
(0.032)^{*}\end{array}$ & $\begin{array}{r}0.048 \\
(0.021)^{*}\end{array}$ & $\begin{array}{r}2.949 \\
(1.882)\end{array}$ & $\begin{array}{r}-0.268 \\
(1.170)\end{array}$ & $\begin{array}{r}7.951 \\
(2.567)^{* *}\end{array}$ \\
\hline Load factor & $\begin{array}{r}0.159 \\
(0.035)^{* *} \\
\end{array}$ & $\begin{array}{r}0.051 \\
(0.023)^{*}\end{array}$ & $\begin{array}{r}10.181 \\
(1.867)^{* *}\end{array}$ & $\begin{array}{r}-1.341 \\
(1.211) \\
\end{array}$ & $\begin{array}{r}9.623 \\
(2.852)^{* *} \\
\end{array}$ \\
\hline $\begin{array}{l}\text { Flights departing } \\
\text { from origination }\end{array}$ & $\begin{array}{r}0.017 \\
(0.030)\end{array}$ & $\begin{array}{r}-0.027 \\
(0.019)\end{array}$ & $\begin{array}{r}1.395 \\
(1.548)\end{array}$ & $\begin{array}{r}1.390 \\
(1.230)\end{array}$ & $\begin{array}{r}5.437 \\
(2.686)^{*}\end{array}$ \\
\hline
\end{tabular}




\begin{tabular}{|l|r|l|r|r|r|}
\hline airport & & & & & \\
\hline $\begin{array}{l}\text { Flights arriving } \\
\text { at destination } \\
\text { airport }\end{array}$ & -0.025 & -0.026 & -1.894 & -3.687 & -2.154 \\
& $(0.027)$ & $(0.015)+$ & $(1.566)$ & $(1.155)^{* *}$ & $(2.389)$ \\
\hline $\mathrm{N}$ & & & & & \\
\hline
\end{tabular}

All models include carrier-route and carrier-quarter fixed effects. Standard errors clustered by carrier-route-pair are reported in parentheses. Models 1 and 2 are marginal effects from fractional logit models, estimated using maximum likelihood, to account for the proportional nature of the dependent variable (Papke \& Wooldridge, 1996).

$\dagger p<.10$

$* p<.05$

$* * p<.01$ 
Table 6

Weighted estimation of incumbents' on-time performance response to entry and entry threats by Southwest

\begin{tabular}{|c|c|c|c|c|c|}
\hline & $\begin{array}{l}\text { Proportion of } \\
\text { flights arriving } \\
\text { at least } 15 \\
\text { minutes late } \\
\end{array}$ & $\begin{array}{l}\text { Proportion of } \\
\text { flights arriving } \\
\text { at least } 30 \\
\text { minutes late } \\
\end{array}$ & $\begin{array}{l}\text { Arrival delay } \\
\text { (minutes) }\end{array}$ & $\begin{array}{l}\text { Scheduled } \\
\text { flight time }\end{array}$ & Travel time \\
\hline $\begin{array}{l}\text { 7-8 quarters } \\
\text { before } \\
\text { Southwest } \\
\text { threatens route }\end{array}$ & $\begin{array}{l}0.016 \\
(0.013)\end{array}$ & $\begin{array}{l}0.011 \\
(0.008)\end{array}$ & $\begin{array}{l}1.376 \\
(0.603)^{*}\end{array}$ & $\begin{array}{l}-0.971 \\
(0.312)^{* *}\end{array}$ & $\begin{array}{l}2.145 \\
(0.871)^{*}\end{array}$ \\
\hline $\begin{array}{l}\text { 5-6 quarters } \\
\text { before } \\
\text { Southwest } \\
\text { threatens route }\end{array}$ & $\begin{array}{l}0.003 \\
(0.010)\end{array}$ & $\begin{array}{l}0.000 \\
(0.006)\end{array}$ & $\begin{array}{l}0.703 \\
(0.499)\end{array}$ & $\begin{array}{l}-0.701 \\
(0.351)^{*}\end{array}$ & $\begin{array}{l}1.127 \\
(0.776)\end{array}$ \\
\hline $\begin{array}{l}\text { 3-4 quarters } \\
\text { before } \\
\text { Southwest } \\
\text { threatens route }\end{array}$ & $\begin{array}{l}0.025 \\
(0.012)^{*}\end{array}$ & $\begin{array}{l}0.011 \\
(0.008)\end{array}$ & $\begin{array}{l}1.627 \\
(0.630)^{*}\end{array}$ & $\begin{array}{l}-0.669 \\
(0.404)+\end{array}$ & $\begin{array}{l}2.594 \\
(0.899)^{* *}\end{array}$ \\
\hline $\begin{array}{l}1-2 \text { quarters } \\
\text { before } \\
\text { Southwest } \\
\text { threatens route }\end{array}$ & $\begin{array}{l}0.036 \\
(0.013)^{* *}\end{array}$ & $\begin{array}{l}0.020 \\
(0.007)^{* *}\end{array}$ & $\begin{array}{l}1.901 \\
(0.677)^{* *}\end{array}$ & $\begin{array}{l}-0.711 \\
(0.523) \\
\end{array}$ & $\begin{array}{l}2.540 \\
(0.924)^{* *}\end{array}$ \\
\hline $\begin{array}{l}\text { Southwest } \\
\text { threatens route }\end{array}$ & $\begin{array}{l}0.030 \\
(0.016)+\end{array}$ & $\begin{array}{l}0.013 \\
(0.008)\end{array}$ & $\begin{array}{l}1.963 \\
(0.819)^{*}\end{array}$ & $\begin{array}{l}-0.745 \\
(0.546)\end{array}$ & $\begin{array}{l}3.474 \\
(1.062)^{* *}\end{array}$ \\
\hline $\begin{array}{l}\text { 1-2 quarters } \\
\text { after Southwest } \\
\text { threatens route } \\
\text { (no flights) }\end{array}$ & $\begin{array}{l}0.027 \\
(0.016)+\end{array}$ & $\begin{array}{l}0.017 \\
(0.010)+\end{array}$ & $\begin{array}{l}1.328 \\
(0.881)\end{array}$ & $\begin{array}{l}-0.597 \\
(0.576) \\
\end{array}$ & $\begin{array}{l}2.094 \\
(1.185)+\end{array}$ \\
\hline $\begin{array}{l}\text { 3-12 quarters } \\
\text { after Southwest } \\
\text { threatens route } \\
\text { (no flights) }\end{array}$ & $\begin{array}{l}0.051 \\
(0.017)^{* *}\end{array}$ & $\begin{array}{l}0.027 \\
(0.009)^{* *}\end{array}$ & $\begin{array}{l}2.812 \\
(0.930)^{* *}\end{array}$ & $\begin{array}{l}-0.707 \\
(0.656)\end{array}$ & $\begin{array}{l}3.626 \\
(1.189)^{* *}\end{array}$ \\
\hline $\begin{array}{l}\text { Southwest } \\
\text { begins flying } \\
\text { route }\end{array}$ & $\begin{array}{l}0.048 \\
(0.019)^{*}\end{array}$ & $\begin{array}{l}0.023 \\
(0.010)^{*}\end{array}$ & $\begin{array}{l}2.655 \\
(1.012)^{* *}\end{array}$ & $\begin{array}{l}-0.885 \\
(0.633)\end{array}$ & $\begin{array}{l}3.376 \\
(1.312)^{*}\end{array}$ \\
\hline $\begin{array}{l}\text { 1-2 quarters } \\
\text { after Southwest } \\
\text { enters route }\end{array}$ & $\begin{array}{l}0.049 \\
(0.019)^{* *}\end{array}$ & $\begin{array}{l}0.026 \\
(0.010)^{*}\end{array}$ & $\begin{array}{l}2.265 \\
(1.023)^{*}\end{array}$ & $\begin{array}{l}-0.768 \\
(0.690)\end{array}$ & $\begin{array}{l}3.400 \\
(1.356)^{*}\end{array}$ \\
\hline $\begin{array}{l}\text { 3-12 quarters } \\
\text { after Southwest } \\
\text { enters route }\end{array}$ & $\begin{array}{l}0.060 \\
(0.021)^{* *}\end{array}$ & $\begin{array}{l}0.034 \\
(0.012)^{* *}\end{array}$ & $\begin{array}{l}3.043 \\
(1.123)^{* *}\end{array}$ & $\begin{array}{l}-1.017 \\
(0.731)\end{array}$ & $\begin{array}{l}4.463 \\
(1.511)^{* *}\end{array}$ \\
\hline Load factor & $\begin{array}{l}0.117 \\
(0.030)^{* *}\end{array}$ & $\begin{array}{l}0.059 \\
(0.019)^{* *}\end{array}$ & $\begin{array}{l}7.182 \\
(1.360)^{* *}\end{array}$ & $\begin{array}{l}-0.509 \\
(0.939)\end{array}$ & $\begin{array}{l}6.551 \\
(1.872)^{* *}\end{array}$ \\
\hline $\begin{array}{l}\text { Flights arriving } \\
\text { at destination } \\
\text { airport }\end{array}$ & $\begin{array}{l}-0.014 \\
(0.023)\end{array}$ & $\begin{array}{l}-0.036 \\
(0.015)^{*}\end{array}$ & $\begin{array}{l}-0.635 \\
(1.065)\end{array}$ & $\begin{array}{l}1.721 \\
(0.970)+\end{array}$ & $\begin{array}{l}2.429 \\
(1.648)\end{array}$ \\
\hline $\begin{array}{l}\text { Flights departing } \\
\text { from origination } \\
\text { airport }\end{array}$ & $\begin{array}{l}-0.015 \\
(0.023)\end{array}$ & $\begin{array}{l}-0.022 \\
(0.013)+\end{array}$ & $\begin{array}{l}-0.600 \\
(1.192)\end{array}$ & $\begin{array}{l}-3.306 \\
(0.940)^{* *}\end{array}$ & $\begin{array}{l}-2.991 \\
(1.792)+\end{array}$ \\
\hline $\mathrm{N}$ & 5200 & 5200 & 5188 & 5188 & 5188 \\
\hline
\end{tabular}


All models include carrier-route and carrier-quarter fixed effects. Standard errors clustered by carrier-route-pair are reported in parentheses. Models 1 and 2 are fractional logit models, estimated using maximum likelihood, to account for the proportional nature of the dependent variable (Papke \& Wooldridge, 1996).

$\dagger p<.10$

$* p<.05$

$* * p<.01$ 
Table 7

Incumbents' on-time performance response to entry and entry threats by Southwest, allowing for carriers to shift resources across routes (includes carrier, route, and quarter fixed effects)

\begin{tabular}{|c|c|c|c|c|c|}
\hline & $\begin{array}{l}\text { Proportion of } \\
\text { flights arriving } \\
\text { at least } 15 \\
\text { minutes late }\end{array}$ & $\begin{array}{l}\text { Proportion of } \\
\text { flights arriving } \\
\text { at least } 30 \\
\text { minutes late }\end{array}$ & $\begin{array}{l}\text { Arrival delay } \\
\text { (minutes) }\end{array}$ & $\begin{array}{l}\text { Scheduled } \\
\text { flight time }\end{array}$ & Travel time \\
\hline $\begin{array}{l}\text { 7-8 quarters } \\
\text { before } \\
\text { Southwest } \\
\text { threatens route }\end{array}$ & $\begin{array}{l}0.057 \\
(0.016)^{* *}\end{array}$ & $\begin{array}{l}0.034 \\
(0.009)^{* *}\end{array}$ & $\begin{array}{l}3.099 \\
(0.768)^{* *}\end{array}$ & $\begin{array}{l}-1.341 \\
(0.417)^{* *}\end{array}$ & $\begin{array}{l}3.293 \\
(1.008)^{* *}\end{array}$ \\
\hline $\begin{array}{l}\text { 5-6 quarters } \\
\text { before } \\
\text { Southwest } \\
\text { threatens route }\end{array}$ & $\begin{array}{l}0.035 \\
(0.014)^{*}\end{array}$ & $\begin{array}{l}0.015 \\
(0.008)+\end{array}$ & $\begin{array}{l}2.074 \\
(0.740)^{* *}\end{array}$ & $\begin{array}{l}-0.965 \\
(0.427)^{*}\end{array}$ & $\begin{array}{l}2.121 \\
(0.922)^{*}\end{array}$ \\
\hline $\begin{array}{l}\text { 3-4 quarters } \\
\text { before } \\
\text { Southwest } \\
\text { threatens route }\end{array}$ & $\begin{array}{l}0.069 \\
(0.015)^{* *}\end{array}$ & $\begin{array}{l}0.038 \\
(0.010)^{* *}\end{array}$ & $\begin{array}{l}3.503 \\
(0.826)^{* *}\end{array}$ & $\begin{array}{l}-0.498 \\
(0.536)\end{array}$ & $\begin{array}{l}4.739 \\
(1.141)^{* *}\end{array}$ \\
\hline $\begin{array}{l}1-2 \text { quarters } \\
\text { before } \\
\text { Southwest } \\
\text { threatens route }\end{array}$ & $\begin{array}{l}0.083 \\
(0.018)^{* *}\end{array}$ & $\begin{array}{l}0.045 \\
(0.011)^{* *}\end{array}$ & $\begin{array}{l}4.060 \\
(0.982)^{* *}\end{array}$ & $\begin{array}{l}-0.756 \\
(0.623)\end{array}$ & $\begin{array}{l}4.907 \\
(1.278)^{* *}\end{array}$ \\
\hline $\begin{array}{l}\text { Southwest } \\
\text { threatens route }\end{array}$ & $\begin{array}{l}0.085 \\
(0.022)^{* *}\end{array}$ & $\begin{array}{l}0.040 \\
(0.014)^{* *}\end{array}$ & $\begin{array}{l}4.375 \\
(1.114)^{* *}\end{array}$ & $\begin{array}{l}-0.933 \\
(0.697)\end{array}$ & $\begin{array}{l}5.930 \\
(1.525)^{* *}\end{array}$ \\
\hline $\begin{array}{l}\text { 1-2 quarters } \\
\text { after Southwest } \\
\text { threatens route } \\
\text { (no flights) }\end{array}$ & $\begin{array}{l}0.083 \\
(0.021)^{* *}\end{array}$ & $\begin{array}{l}0.050 \\
(0.013)^{*}\end{array}$ & $\begin{array}{l}4.092 \\
(1.200)^{* *}\end{array}$ & $\begin{array}{l}-0.896 \\
(0.747)\end{array}$ & $\begin{array}{l}4.810 \\
(1.506)^{* *}\end{array}$ \\
\hline $\begin{array}{l}\text { 3-12 quarters } \\
\text { after Southwest } \\
\text { threatens route } \\
\text { (no flights) }\end{array}$ & $\begin{array}{l}0.111 \\
(0.026)^{* *}\end{array}$ & $\begin{array}{l}0.064 \\
(0.015)^{* *}\end{array}$ & $\begin{array}{l}5.500 \\
(1.384)^{* *}\end{array}$ & $\begin{array}{l}-0.891 \\
(0.850)\end{array}$ & $\begin{array}{l}6.286 \\
(1.724)^{* *}\end{array}$ \\
\hline $\begin{array}{l}\text { Southwest } \\
\text { begins flying } \\
\text { route }\end{array}$ & $\begin{array}{l}0.113 \\
(0.021)^{* *}\end{array}$ & $\begin{array}{l}0.059 \\
(0.015)^{* *}\end{array}$ & $\begin{array}{l}5.550 \\
(1.327)^{* *}\end{array}$ & $\begin{array}{l}-0.763 \\
(0.796)\end{array}$ & $\begin{array}{l}6.252 \\
(1.682)^{* *}\end{array}$ \\
\hline $\begin{array}{l}\text { 1-2 quarters } \\
\text { after Southwest } \\
\text { enters route }\end{array}$ & $\begin{array}{l}0.134 \\
(0.027)^{* *}\end{array}$ & $\begin{array}{l}0.076 \\
(0.017)^{* *}\end{array}$ & $\begin{array}{l}6.136 \\
(1.427)^{* *}\end{array}$ & $\begin{array}{l}-0.854 \\
(0.859)\end{array}$ & $\begin{array}{l}7.944 \\
(2.041)^{* *}\end{array}$ \\
\hline $\begin{array}{l}\text { 3-12 quarters } \\
\text { after Southwest } \\
\text { enters route }\end{array}$ & $\begin{array}{l}0.145 \\
(0.029)^{* *}\end{array}$ & $\begin{array}{l}0.085 \\
(0.019)^{* *}\end{array}$ & $\begin{array}{l}6.955 \\
(1.577)^{* *}\end{array}$ & $\begin{array}{l}-1.023 \\
(0.981)\end{array}$ & $\begin{array}{l}8.110 \\
(2.134)^{* *}\end{array}$ \\
\hline Load factor & $\begin{array}{l}0.143 \\
(.034)^{* *}\end{array}$ & $\begin{array}{l}0.050 \\
(0.022)^{*}\end{array}$ & $\begin{array}{l}8.315 \\
(1.938)^{* *}\end{array}$ & $\begin{array}{l}-1.430 \\
(1.211)\end{array}$ & $\begin{array}{l}8.560 \\
(2.024)^{* *}\end{array}$ \\
\hline $\begin{array}{l}\text { Flights arriving } \\
\text { at destination } \\
\text { airport during } \\
\text { same hour }\end{array}$ & $\begin{array}{l}0.041 \\
(0.024)+\end{array}$ & $\begin{array}{l}0.003 \\
(0.015)\end{array}$ & $\begin{array}{l}2.303 \\
(1.224)+\end{array}$ & $\begin{array}{l}2.606 \\
(0.999)^{*}\end{array}$ & $\begin{array}{l}4.345 \\
(1.789)^{*}\end{array}$ \\
\hline $\begin{array}{l}\text { Flights departing } \\
\text { from origination } \\
\text { airport during }\end{array}$ & $\begin{array}{l}0.011 \\
(0.023)\end{array}$ & $\begin{array}{l}-0.009 \\
(0.016)\end{array}$ & $\begin{array}{l}0.241 \\
(1.354)\end{array}$ & $\begin{array}{l}-1.550 \\
(0.900)+\end{array}$ & $\begin{array}{l}-1.969 \\
(2.009)\end{array}$ \\
\hline
\end{tabular}




\begin{tabular}{|l|l|l|l|l|l|}
\hline same hour & & & & & \\
\hline & & & & & \\
\hline $\mathrm{N}$ & 5200 & 5200 & 5199 & 5199 & 5199 \\
\hline
\end{tabular}

All models include carrier, route, and quarter fixed effects. Standard errors clustered by carrierroute are reported in parentheses. Models 1 and 2 are marginal effects from fractional logit models, estimated using maximum likelihood, to account for the proportional nature of the dependent variable (Papke \& Wooldridge, 1996).

$\dagger p<.10$

$* p<.05$

$* * p<.01$ 
Table 8

Alternative measures of incumbents' service quality response to entry and entry threats by Southwest

\begin{tabular}{|c|c|c|}
\hline & $\begin{array}{l}\text { Proportion of } \\
\text { flights } \\
\text { cancelled }\end{array}$ & $\begin{array}{l}\text { Ln(Number of } \\
\text { departures) }\end{array}$ \\
\hline $\begin{array}{l}\text { 7-8 quarters } \\
\text { before } \\
\text { Southwest } \\
\text { threatens route }\end{array}$ & $\begin{array}{l}0.001 \\
(0.001)\end{array}$ & $\begin{array}{l}0.002 \\
(0.038)\end{array}$ \\
\hline $\begin{array}{l}\text { 5-6 quarters } \\
\text { before } \\
\text { Southwest } \\
\text { threatens route }\end{array}$ & $\begin{array}{l}-0.002 \\
(0.002)\end{array}$ & $\begin{array}{l}0.052 \\
(0.048)\end{array}$ \\
\hline $\begin{array}{l}\text { 3-4 quarters } \\
\text { before } \\
\text { Southwest } \\
\text { threatens route }\end{array}$ & $\begin{array}{l}-0.002 \\
(0.002)\end{array}$ & $\begin{array}{l}0.119 \\
(0.056)^{*}\end{array}$ \\
\hline $\begin{array}{l}1-2 \text { quarters } \\
\text { before } \\
\text { Southwest } \\
\text { threatens route }\end{array}$ & $\begin{array}{l}-0.003 \\
(0.002)+\end{array}$ & $\begin{array}{l}0.177 \\
(0.067)^{* *}\end{array}$ \\
\hline $\begin{array}{l}\text { Southwest } \\
\text { threatens route }\end{array}$ & $\begin{array}{l}-0.003 \\
(0.002)\end{array}$ & $\begin{array}{l}0.213 \\
(0.079)^{* *}\end{array}$ \\
\hline $\begin{array}{l}\text { 1-2 quarters } \\
\text { after Southwest } \\
\text { threatens route } \\
\text { (no flights) }\end{array}$ & $\begin{array}{l}-0.004 \\
(0.002)+\end{array}$ & $\begin{array}{l}0.197 \\
(0.085)^{*}\end{array}$ \\
\hline $\begin{array}{l}\text { 3-12 quarters } \\
\text { after Southwest } \\
\text { threatens route } \\
\text { (no flights) }\end{array}$ & $\begin{array}{l}-0.003 \\
(0.003)\end{array}$ & $\begin{array}{l}0.181 \\
(0.094)+\end{array}$ \\
\hline $\begin{array}{l}\text { Southwest } \\
\text { begins flying } \\
\text { route }\end{array}$ & $\begin{array}{l}-0.002 \\
(0.003)\end{array}$ & $\begin{array}{l}0.251 \\
(0.098)^{*}\end{array}$ \\
\hline $\begin{array}{l}\text { 1-2 quarters } \\
\text { after Southwest } \\
\text { enters route }\end{array}$ & $\begin{array}{l}-0.003 \\
(0.003)\end{array}$ & $\begin{array}{l}0.281 \\
(0.105)^{* *}\end{array}$ \\
\hline $\begin{array}{l}\text { 3-12 quarters } \\
\text { after Southwest } \\
\text { enters route }\end{array}$ & $\begin{array}{l}-0.005 \\
(0.003)\end{array}$ & $\begin{array}{l}0.370 \\
(0.122)^{* *}\end{array}$ \\
\hline Load factor & $\begin{array}{l}-0.038 \\
(0.004)^{* *}\end{array}$ & $\begin{array}{l}-0.344 \\
(0.127)^{* *}\end{array}$ \\
\hline $\begin{array}{l}\text { Flights arriving } \\
\text { at destination } \\
\text { airport during } \\
\text { same hour }\end{array}$ & $\begin{array}{l}-0.002 \\
(0.003)\end{array}$ & $\begin{array}{l}0.387 \\
(0.104)^{* *}\end{array}$ \\
\hline $\begin{array}{l}\text { Flights departing } \\
\text { from origination } \\
\text { airport during } \\
\text { same hour } \\
\end{array}$ & $\begin{array}{l}-0.005 \\
(0.003)\end{array}$ & $\begin{array}{l}0.402 \\
(0.114)^{* *}\end{array}$ \\
\hline
\end{tabular}


\begin{tabular}{|l|l|l|}
\hline $\mathrm{N}$ & 5200 & 5189 \\
\hline
\end{tabular}

All models include carrier-route and carrier-quarter fixed effects. Standard errors clustered by carrier-route-pair are reported in parentheses. Model 1 shows marginal effects from fractional logit models, estimated using maximum likelihood, to account for the proportional nature of the dependent variable (Papke \& Wooldridge, 1996).

$\dagger p<.10$

$* p<.05$

$* * p<.01$ 


\section{APPENDIX}

\section{A.1. Equilibrium Solution Details}

In this section, we provide the details for the three equilibrium solutions presented in Section 2.1.

Duopoly with same costs:

To ensure sufficient heterogeneity (which will ensure prices are non-negative) and that the market is covered, we make the following two assumptions:

Assumption 1: $\bar{\theta} \geq 2 \underline{\theta}$

Assumption 2: $\frac{(\bar{\theta}-2 \underline{\theta}) *\left(s_{H}-s_{L}\right)+c\left(s_{H}^{2}+2 s_{L}^{2}\right)}{3} \leq \underline{\theta} s_{L}$

To solve the model, we can write demand and profits for each firm as follows:

$$
\begin{gathered}
D_{L}=\frac{p_{H}-p_{L}}{s_{H}-s_{L}}-\underline{\theta} \\
D_{H}=\bar{\theta}-\frac{p_{H}-p_{L}}{s_{H}-s_{L}} \\
\pi_{L}=\left(\frac{p_{H}-p_{L}}{s_{H}-s_{L}}-\underline{\theta}\right) *\left(p_{L}-c s_{L}^{2}\right) \\
\pi_{H}=\left(\bar{\theta}-\frac{p_{H}-p_{L}}{s_{H}-s_{L}}\right) *\left(p_{H}-c s_{H}^{2}\right)
\end{gathered}
$$

In the second stage, we take location choices as given, and solve first order conditions in prices to arrive at equilibrium prices and profits, which are:

$$
\begin{aligned}
& p_{L}^{*}=\frac{(\bar{\theta}-2 \underline{\theta}) *\left(s_{H}-s_{L}\right)+c\left(s_{H}^{2}+2 s_{L}^{2}\right)}{3} \\
& p_{H}^{*}=\frac{(2 \bar{\theta}-\underline{\theta}) *\left(s_{H}-s_{L}\right)+c\left(2 s_{H}^{2}+s_{L}^{2}\right)}{3}
\end{aligned}
$$




$$
\begin{aligned}
& \pi_{L}^{*}=\frac{\left(\bar{\theta}-2 \underline{\theta}+c\left(s_{H}+s_{L}\right)\right)^{2} *\left(s_{H}-s_{L}\right)}{9} \\
& \pi_{H}^{*}=\frac{\left(2 \bar{\theta}-\underline{\theta}-c\left(s_{H}+s_{L}\right)\right)^{2} *\left(s_{H}-s_{L}\right)}{9}
\end{aligned}
$$

Equilibrium location choices in the first stage are determined by solving first order conditions for the above profit functions in location choices (and verifying second order sufficient conditions), the solution to which is in Section 2.

Monopoly:

To solve the model, we can write demand and profits for the monopolist as follows:

$$
\begin{gathered}
D=\bar{\theta}-\frac{p}{s} \\
\pi=\left(\bar{\theta}-\frac{p}{s}\right) *\left(p-c s^{2}\right)
\end{gathered}
$$

In the second stage, it is easy to show that equilibrium prices and profits are:

$$
\begin{gathered}
p^{*}=\frac{(c s+\bar{\theta}) s}{2} \\
\pi^{*}=\left(\frac{\bar{\theta}-c s}{2}\right)^{2} * s
\end{gathered}
$$

Equilibrium location choice in the first stage simply optimizes the above profit function in s, the solution to which is reported in Section 2.

\section{Duopoly with differing costs:}

To solve the model, we can write demand and profits for each firm as follows ${ }^{15}$ :

$$
\begin{aligned}
D_{L} & =\frac{p_{H}-p_{L}}{s_{H}-s_{L}}-\underline{\theta} \\
D_{H} & =\bar{\theta}-\frac{p_{H}-p_{L}}{s_{H}-s_{L}}
\end{aligned}
$$

\footnotetext{
${ }^{15}$ Note that subscripts here generically refer to the firm that goes High or Low. For example, $\mathrm{C}_{\mathrm{L}}$ refers to the cost for the firm that goes Low, and so would equal $c_{1}$ if Firm 1 went Low.
} 


$$
\begin{aligned}
\pi_{L} & =\left(\frac{p_{H}-p_{L}}{s_{H}-s_{L}}-\underline{\theta}\right) *\left(p_{L}-c_{L} s_{L}^{2}\right) \\
\pi_{H} & =\left(\bar{\theta}-\frac{p_{H}-p_{L}}{s_{H}-s_{L}}\right) *\left(p_{H}-c_{H} s_{H}^{2}\right)
\end{aligned}
$$

In the second stage, we take location choices as given, and solve first order conditions in prices to arrive at equilibrium prices and profits, which are:

$$
\begin{aligned}
p_{L}^{*} & =\frac{(\bar{\theta}-2 \underline{\theta}) *\left(s_{H}-s_{L}\right)+2 c_{L} s_{L}^{2}+c_{H} s_{H}^{2}}{3} \\
p_{H}^{*} & =\frac{(2 \bar{\theta}-\underline{\theta}) *\left(s_{H}-s_{L}\right)+2 c_{H} s_{H}^{2}+c_{L} s_{L}^{2}}{3} \\
\pi_{L}^{*} & =\frac{\left((\bar{\theta}-2 \underline{\theta}) *\left(s_{H}-s_{L}\right)+c_{H} s_{H}^{2}-c_{L} s_{L}^{2}\right)^{2}}{9\left(s_{H}-s_{L}\right)} \\
\pi_{H}^{*} & =\frac{\left((2 \bar{\theta}-\underline{\theta}) *\left(s_{H}-s_{L}\right)+c_{L} s_{L}^{2}-c_{H} s_{H}^{2}\right)^{2}}{9\left(s_{H}-s_{L}\right)}
\end{aligned}
$$

Then, in the first stage, the first order conditions are:

$$
\begin{aligned}
& \left(2 \underline{\theta}-\bar{\theta}-4 c_{L} s_{L}\right)\left(s_{H}-s_{L}\right)-c_{L} s_{L}^{2}+c_{H} s_{H}^{2}=0 \\
& \left(2 \bar{\theta}-\underline{\theta}-4 c_{H} s_{H}\right)\left(s_{H}-s_{L}\right)-c_{L} s_{L}^{2}+c_{H} s_{H}^{2}=0
\end{aligned}
$$

Unfortunately, this leaves us with two non-linear equations in two unknowns. However, we can deduce the following from the above equations. First, combining the two first order conditions, we have:

$$
\frac{3}{4}(\bar{\theta}-\underline{\theta})=c_{H} s_{H}-c_{L} s_{L}
$$

In principle, this condition could be satisfied if $\mathrm{s}_{\mathrm{H}}=\mathrm{s}_{\mathrm{L}}$. However, looking again at the first order conditions, this can only occur if $s_{H}=s_{L}=0$. However, the second partials are non-negative for 
both variables when evaluated at 0 , so this would not be an optimum. Hence, we again have differentiation in equilibrium.

Lastly, for a given location pair ( $\mathrm{s}_{\mathrm{L}}, \mathrm{s}_{\mathrm{H}}$ ), we can derive the conditions under which $\pi_{\mathrm{L}}+\pi_{\mathrm{H}}$ is greater when $\mathrm{c}_{\mathrm{H}}=\mathrm{c}_{2}$ compared to when $\mathrm{c}_{\mathrm{H}}=\mathrm{c}_{1}$. In words, we want to determine the conditions under which it is more profitable in the aggregate for the low-cost firm $\left(c_{2}\right)$ to go high than when the low-cost firm goes low. Given locations, we need only simplify when:

$$
\begin{gathered}
\frac{\left((\bar{\theta}-2 \underline{\theta}) *\left(s_{H}-s_{L}\right)+c_{2} s_{H}^{2}-c_{1} s_{L}^{2}\right)^{2}}{9\left(s_{H}-s_{L}\right)}+\frac{\left((2 \bar{\theta}-\underline{\theta}) *\left(s_{H}-s_{L}\right)+c_{1} s_{L}^{2}-c_{2} s_{H}^{2}\right)^{2}}{9\left(s_{H}-s_{L}\right)}> \\
\frac{\left((\bar{\theta}-2 \underline{\theta}) *\left(s_{H}-s_{L}\right)+c_{1} s_{H}^{2}-c_{2} s_{L}^{2}\right)^{2}}{9\left(s_{H}-s_{L}\right)}+\frac{\left((2 \bar{\theta}-\underline{\theta}) *\left(s_{H}-s_{L}\right)+c_{2} s_{L}^{2}-c_{1} s_{H}^{2}\right)^{2}}{9\left(s_{H}-s_{L}\right)}
\end{gathered}
$$

With a bit of algebraic simplification, this inequality becomes:

$$
c_{1}+c_{2}<\frac{\bar{\theta}+\underline{\theta}}{s_{L}+s_{H}}
$$

To ensure this inequality holds for any location pair, we can replace the denominator with the highest possible values for $\mathrm{s}_{\mathrm{L}}$ and $\mathrm{s}_{\mathrm{H}}, \bar{\theta}$. Therefore, this inequality will hold for any location pair if we have:

$$
c_{1}+c_{2}<\frac{\bar{\theta}+\underline{\theta}}{2 \bar{\theta}}=\frac{1}{2}+\frac{\underline{\theta}}{2 \bar{\theta}}
$$

\section{A.2. Worse On-time Performance as a Means of Entry Deterrence}

In this section, we discuss in greater detail how providing worse on-time performance may be a component of a larger entry deterrence strategy (involving price cutting) to generate customer loyalty. To see this, we provide a simple example. Specifically, we consider a case where an incumbent monopolist wishes to maximize current demand subject to a profit 
constraint. That is, the incumbent is willing to lose some money (relative to the profit maximum) in the short-run to increase current demand and hopefully long-run switching costs. Hence, it seeks the optimal price/quality combination that maximizes current demand subject to a given profit loss. For our example, let demand be:

(1) $Q=z-a * P+b * L+c * P * L$

Here, $Q$ is quantity, $P$ is price, $L$ is quality, and $<z, a, b, c>$ is a vector of scalars. Note that the last term allows sensitivity to quality to depend on the price. We further assume that marginal costs of production are zero, but there is an increasing fixed cost of quality provision:

(2) $F(L)=d * L^{2}$

Here, $d$ is another scalar. When an entry threat emerges, the monopolist then solves the following:

(3) $\operatorname{Max}_{P, L} z-a * P+b * L+c * P * L$

s.t. $\Pi^{*}-\Pi(P, L) \leq K$

Here, $\Pi^{*}$ are maximal monopoly profits, $\Pi(P, L)=P * Q-d * L^{2}$ are profits as a function of price and quality, and $K$ is the amount of lost current profits the firm is willing to tolerate in order to boost short-run demand. In short, the monopolist chooses price and quality to maximize present demand subject to a given profit loss. For a wide range of parameters (with $\mathrm{c}>0$ ), the solution to (3) involves a quality choice that is unambiguously lower than the quality choice that would achieve $\Pi^{*}$. For example, when we set $\left.<\mathrm{z}, \mathrm{a}, \mathrm{b}, \mathrm{c}, \mathrm{d}\right\rangle=\langle 40,10,0.05,0.10,10>$ and $\mathrm{K}=8$, the constrained demand-maximizing quality choice is $7 \%$ lower than the profit-maximizing quality choice (further, the price is $45 \%$ lower, consistent with a price and quality slashing strategy to boost demand). Hence, the entry deterrent quality level is lower than the monopoly level. Intuitively, this is because the marginal profit from lowering quality and price from pre-entry (and pre-entry threat) levels is positive. 